Environmental Pollution

September 2016, Volume 216, Pages 724-737

http://dx.doi.org/10.1016/i.envpol.2016.06.039

http://archimer.ifremer.fr/doc/00344/45502/

(c) 2016 Elsevier Ltd. All rights reserved.

\title{
Exposure of marine mussels Mytilus spp. to polystyrene microplastics: Toxicity and influence on fluoranthene bioaccumulation
}

\author{
Paul-Pont Ika ${ }^{1,{ }^{*}}$, Lacroix Camille ${ }^{1,2}$, González Fernández Carmen ${ }^{3}$, Hégaret Helene ${ }^{1}$, \\ Lambert Christophe ${ }^{1}$, Le Goïc Nelly ${ }^{1}$, Frère Laura ${ }^{1}$, Cassone Anne-Laure ${ }^{1}$, Sussarellu Rossana ${ }^{4}$, \\ Fabioux Caroline ${ }^{1}$, Guyomarch Julien ${ }^{2}$, Albentosa Marina ${ }^{3}$, Huvet Arnaud ${ }^{5}$, Soudant Philippe ${ }^{1}$
}

${ }^{1}$ Laboratoire des Sciences de l'Environnement Marin (LEMAR), UMR 6539 CNRS/UBO/IRD/IFREMER

- Institut Universitaire Européen de la Mer, Technopôle Brest-Iroise - Rue Dumont d'Urville, 29280

Plouzané, France

${ }^{2}$ CEDRE, 715 rue Alain Colas, 29218 BREST Cedex 2, France

${ }^{3}$ Instituto Español de Oceanografía, IEO, Centro Oceanográfico de Murcia, Varadero 1, E-30740 San

Pedro del Pinatar, Murcia, Spain

${ }^{4}$ Ifremer, Laboratoired'Ecotoxicologie, Nantes, France

${ }^{5}$ Ifremer, Laboratoire des Sciences de I'Environnement Marin (LEMAR), UMR 6539

UBO/CNRS/IRD/Ifremer), Centre Bretagne - ZI de la Pointe du Diable - CS 10070, 29280 Plouzané, France

* Corresponding author : Ika Paul-Pont, email address : ika.paulpont@univ-brest.fr

\begin{abstract}
:
The effects of polystyrene microbeads (micro-PS; mix of 2 and $6 \mu \mathrm{m}$; final concentration: $32 \mu \mathrm{L} \mathrm{L}^{-1}$ ) alone or in combination with fluoranthene $\left(30 \mu \mathrm{g} \mathrm{L}^{-1}\right)$ on marine mussels Mytilus spp. were investigated after 7 days of exposure and 7 days of depuration under controlled laboratory conditions. Overall, fluoranthene was mostly associated to algae Chaetoceros muelleri (partition coefficient Log Kp $=4.8$ ) used as a food source for mussels during the experiment. When micro-PS were added in the system, a fraction of FLU transferred from the algae to the microbeads as suggested by the higher partition coefficient of micro-PS (Log Kp =6.6), which confirmed a high affinity of fluoranthene for polystyrene microparticles. However, this did not lead to a modification of fluoranthene bioaccumulation in exposed individuals, suggesting that micro-PS had a minor role in transferring fluoranthene to mussels tissues in comparison with waterborne and foodborne exposures. After depuration, a higher fluoranthene concentration was detected in mussels exposed to micro-PS and fluoranthene, as compared to mussels exposed to fluoranthene alone. This may be related to direct effect of micro-PS on detoxification mechanisms, as suggested by a down regulation of a P-glycoprotein involved in pollutant excretion, but other factors such as an impairment of the filtration activity or presence of remaining beads in the gut cannot be excluded. Micro-PS alone led to an increase in hemocyte mortality and triggered substantial modulation of cellular oxidative balance: increase in reactive oxygen species production in hemocytes and enhancement of anti-oxidant and glutathione-related enzymes in mussel tissues. Highest histopathological damages and levels of anti-oxidant markers were observed in mussels exposed to micro-PS together with fluoranthene. Overall these results suggest that under the experimental
\end{abstract}


conditions of our study micro-PS led to direct toxic effects at tissue, cellular and molecular levels, and modulated fluoranthene kinetics and toxicity in marine mussels.

\section{Graphical abstract :}

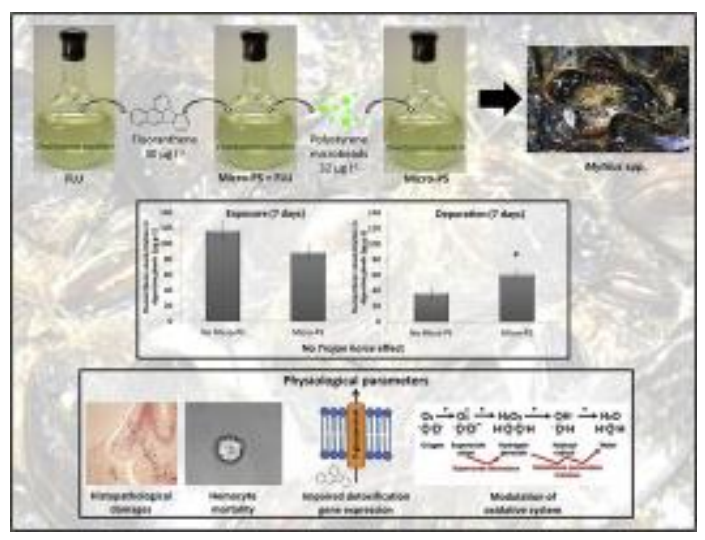

\section{Highlights}

- Micro-PS exhibited high sorption capacity for fluoranthene. Micro-PS did not modify fluoranthene bioaccumulation in marine mussels. Micro-PS exposure modulated oxidative and energetic processes in mussels. An increase in hemocyte mortality was observed in all exposed mussels. Combined exposure led to highest tissue alterations and anti-oxidant marker levels.

Keywords : Microplastics, Fluoranthene, Mussel, Depuration, Oxidative system 


\section{Introduction}

Pollution of the oceans by microplastics, defined as plastic particles of size below $<5 \mathrm{~mm}$ (NOAA, 2008), originate from the accidental release of primary manufactured plastic particles of micrometric size used in many industrial and household activities (blasting, exfoliates, toothpastes, synthetic clothing), as well as from the fragmentation of larger plastics in the environment (Andrady, 2011). Quantitative studies on micro-debris in open oceans and in intertidal zones in the vicinity of industrial cities have confirmed the ubiquitous nature of microplastics (Eriksen et al., 2014). According to these authors, microplastics represent more than $92 \%$ of the total plastic debris $(>0.33 \mathrm{~mm})$ floating at sea, estimated at 5.25 trillion particles in worldwide marine environments. Ingestion of microplastic by marine organisms leading to substantial impacts on major physiological functions such as respiration, nutrition, reproduction, growth and survival has been shown in marine vertebrates and invertebrates (for review see Wright et al., 2013). In addition to physical injuries, the ability of microplastics to efficiently adsorb persistent organic pollutants (POP) has led to an increasing concern related to a potential role of microplastics as vector of POP into marine organisms (Cole et al., 2011, Ivar do Sul and Costa, 2014; Koelmans et al., 2014). Desorption of persistent organic pollutants (POP) from microplastics was demonstrated to be enhanced under in vitro simulated digestive conditions (Bakir et al., 2014). In vivo experiments conducted on fish (Oliveira et al., 2013; Rochman et al., 2013), mussels (Avio et al., 2015) and lugworms (Besseling et al., 2013) revealed the transfer of chemicals after ingestion of contaminated microplastics, as well as combined effects of both contaminants on neurotransmission, energy production and oxidative metabolism. However, recent studies questioned the importance of such transfer in natural conditions given (i) the baseline contamination levels of seawater and marine organisms and (ii) the low proportion of microplastics in comparison with other suspended particles (organic matter, plankton, detritus, etc.) capable of transferring pollutants probably more efficiently due to their higher abundance in marine ecosystems (Herzke et al., 2016; Koelmans et al., 2016). Therefore, laboratory studies aiming to understand the relative sorption of POP to microplastics in comparison to other 
occurring media in marine ecosystems are needed to clarify their respective role as vector of organic pollutant for marine organisms.

The present study aims to investigate experimentally (i) the affinity of fluoranthene (FLU) for polystyrene microparticles (micro-PS) in comparison to phytoplankton by assessing its partition among seawater, micro-PS, and marine algae Chaetoceros muelleri used as a food source for mussels; (ii) whether the presence of loaded micro-PS alongside with contaminated algae and seawater may affect FLU bioaccumulation and depuration in marine mussels Mytilus spp., a common biological model in ecotoxicological studies (Kim et al., 2008); and (iii) the effects of micro-PS exposure alone or in combination with FLU on various physiological parameters at tissue, cellular and molecular levels to provide a comprehensive assessment of pollutant-related effects (Lyons et al., 2010). Fluoranthene was selected as (i) it is a model PAH belonging to the list of priority substances in water policy of the European Commission (Directive 2008/105/EC) and (ii) it constitutes one of the most abundant PAH found in the aquatic environment and in molluscs (Baumard et al., 1998; Bouzas et al., 2011). It is noteworthy that in most of the cited studies, as well as in our work, animals were acclimatized and then reared in "clean water" (seawater filtered on active carbon filters in our case) and exposures were performed in clean and controlled laboratory conditions. This is far from what may happen in natural environments where a wide range of confounding factors is likely to occur (and influence for instance the interaction between fluoranthene and polystyrene microplastics). However, due to the high complexity characterizing natural environments, controlled laboratory experiments remain necessary as a step by step approach for understanding processes, to assess the weight of each factor (in this case microplastics, food and fluoranthene) and sort out complexity of environmental pollution.

\section{Material and methods}

1. Mussel collection and acclimatization 
et al., 2015). The sampling site is located within a zone of overlap between M. edulis and $M$. galloprovincialis (Bierne, 2003), the mussel population is thus considered as a "species complex" (Lacroix et al., 2014a), and is referred to as Mytilus spp. Mussels were acclimatized in a flowthrough aerated 100L-tank supplied with natural filtered seawater $(20,10,5$ and $1 \mu \mathrm{m}$ mesh size; active carbon filter) for 6 weeks. Mussels were fed daily with diatoms (Chaetoceros muelleri) using peristaltic pumps at a ratio of $3 \% \mathrm{w} / \mathrm{w}$ organic matter per gram of mussel tissue (dry weight, $\mathrm{dw}$ ) during the acclimation phase in order to maintain bivalves in healthy conditions. The average dry weight was $0.65 \mathrm{~g}$ per individual.

2. Mussel exposure

After the acclimation, mussels were transferred to 30L tanks (24 mussels per tank) filled with filtered seawater maintained at $17.2 \pm 1.3^{\circ} \mathrm{C}($ mean $\pm \mathrm{SD})$. Four experimental conditions were set up in triplicates: control, FLU (fluoranthene), micro-PS (polystyrene microbeads) and microPS+FLU (fluoranthene and polystyrene microbeads). Control mussels were not exposed to any stressor (micro-PS or fluoranthene) and were fed daily with fresh C.muelleri culture. Exposed mussels were subjected to daily doses of fluoranthene (FLU) set at $30 \mu \mathrm{g} \mathrm{L}^{-1}$ day $^{-1}$ and/or monodisperse yellow-green fluorescent polystyrene beads (micro-PS) (Polysciences) supplied together with the daily prepared algal culture (C. muelleri) for a period of 7 days. Micro-PS of different sizes were used in order to reflect the spectra of food particles ingested by mussels in natural environments (Ward and Shumway, 2004): $2 \mu \mathrm{m}\left(1800\right.$ microbeads $\mathrm{mL}^{-1} \mathrm{day}^{-1}$ ) and $6 \mu \mathrm{m}$ (200 microbeads $\mathrm{mL}^{-1}$ day $^{-1}$ ) beads, obtaining a final concentration of 2000 microbeads $\mathrm{mL}^{-1}$ day ${ }^{1}$. This corresponded to a mass concentration of $32 \mu \mathrm{g} \mathrm{PS} \mathrm{L}^{-1}$ day $^{-1}$. The leaching of chemicals (styrene, additive and fluorochrome) and organic compounds from the micro-PS used in this study was tested; plastics did not release compounds at significant levels above $0.1 \mathrm{ng} \mathrm{L^{-1 }}$, the detection limit of the technique (Sussarellu et al., 2016).

The stock solution of FLU (98\% purity, Sigma Aldrich) was prepared in acetone at a concentration of $1 \mathrm{~g} \mathrm{~L}^{-1}$ before being added to the algal culture (acetone final concentration in the 
algal culture flask $<0.04 \% \mathrm{v} / \mathrm{v}$ and in the mussel tank $<0.003 \% \mathrm{v} / \mathrm{v})$. Micro-PS were added to the algal culture with a light non-ionic detergent (Tween 20 - final concentration in the algal culture flask of $0.0001 \% \mathrm{v} / \mathrm{v}$ leading to a final concentration in the mussel tank below $0.00001 \% \mathrm{v} / \mathrm{v}$ ) in order to minimize micro-PS clumping and sticking to the flask walls. Acetone and Tween 20 were consistently added at the same concentrations to all algal cultures (supplying control, FLU, microPS and micro-PS+FLU tanks) in order to prevent confounding effects due to solvents and detergents. Direct impacts of acetone, tween, FLU and micro-PS were evaluated on algae over a $24 \mathrm{~h}$ period prior to the experiment. No significant effects were observed on biochemical composition, concentration and viability of algae (data not shown). The final concentrations of acetone $(0.003 \%)$ and Tween-20 $(0.00001 \%)$ in the experimental tanks were much lower than the toxic levels reported for marine invertebrates (Rodrigues et al., 2013; Ostroumov, 2003; Sussarellu et al. 2016).

Once micro-PS and FLU were added to the algal cultures, the daily prepared mixtures were gently stirred for 45 minutes before being supplied to the tanks containing the mussels using peristaltic pumps (flow rate: $6.5 \mathrm{mLmin}^{-1}$; feeding duration: $5 \mathrm{~h}$ ). The food ratio for control and exposed mussels was $1.5 \%$ organic matter per gram of mussel tissue per day, corresponding to $210^{5}$ cells $\mathrm{mL}^{-1}$ per tank per day. As the average mass per cell is $45.8 \mathrm{pg} \mathrm{cell}^{-1}$ for $C$. muelleri (Robert et al., 2004), the quantity of algae added per tank per day was $9.16 \mathrm{mg} \mathrm{L}^{-1}$. The relative proportions of PS/FLU/algae was around 1/1/289 given the concentration of each component (micro-PS=32 $\mu \mathrm{g} / \mathrm{L} ; \mathrm{FLU}=30 \mu \mathrm{g} / \mathrm{L} ;$ Algae $\left.=9160 \mu \mathrm{gL}^{-1}\right)$. In order to ascertain that the mussels efficiently ingested algae and were not overfed, water samples were daily collected at the end of the feeding period to assess the concentration of algae remaining in the mussels tanks by flow cytometry. No algae were detected in water or at the bottom of the tanks, suggesting adequate food consumption. Preliminary experiments were performed to ensure that sorption of fluoranthene inside the peristaltic tubes remained negligible and that no extra polymer particles were produced by the tubing wear. 
During the 7 days of exposure, mortality monitoring and water renewal were performed daily prior

to the addition of food (with and without contaminants). At the end of the exposure period, mussels were cleaned (i.e. the shells were carefully brushed and rinsed to avoid any transfer of micro-PS or FLU) and transferred to clean 30L tanks for 7 days of depuration with similar seawater and food conditions as those used during the exposure phase.

3. Assessment of fluoranthene partition in algal cultures

The partition of fluoranthene among seawater, marine algae and micro-PS was assessed after 45 min of contact (time for which the algae cultures started to be supplied to the tanks containing the mussels) and also after $5 \mathrm{~h}$ of contact (time for which the food supply stopped) in the "FLU" and “micro-PS+FLU” algal cultures. For each time point, $10 \mathrm{ml}$ of each algal culture were sampled and centrifuged at $2000 \mathrm{rpm}$ for $10 \mathrm{~min}$ at $4^{\circ} \mathrm{C}$ to pellet the algae. The $6 \mu \mathrm{m}$ beads exhibited similar size and density than C. muelleri cells; therefore it was impossible to discriminate them from the algal cells using classical centrifugation or filtration methods. As a consequence, $>90 \%$ of the $6 \mu \mathrm{m}$ beads was pelleted with the algae. Due to their lower size and density, the $2 \mu \mathrm{m}$ beads remained in suspension. Microscopical examinations were backed up by flow cytometry analyses to confirm that $>95 \%$ of the $2 \mu \mathrm{m}$ micro-PS remained in the supernatant, and $>98 \%$ of the algae alongside with $>90 \%$ of the $6 \mu \mathrm{m}$ beads were pelleted after centrifugation. The supernatant was filtered on a fiberglass filter (Whatman, $0.7 \mu \mathrm{m}$ mesh) to retain the $2 \mu \mathrm{m}$ micro-PS. The filter and the filtrate were separately kept to assess the quantity of fluoranthene associated with the $2 \mu \mathrm{m}$ microbeads (F2) and dissolved in seawater (Fd), respectively. The pellet (containing algae and the $6 \mu \mathrm{m}$ micro-PS) was re-suspended in $4 \mathrm{ml}$ ethanol absolute (molecular grade) and this was used to measure the quantity of fluoranthene associated with the pellet $(\mathrm{Fp})$. The fractions of FLU dissolved in water (Fd) and associated with the $2 \mu \mathrm{m}$ micro-PS (F2) were directly measured using a Stir Bar Sorptive Extraction-Thermal Desorption-Gas Chromatography-Mass Spectrometry (SBSE-TD-GC-MS) method as described below. The fraction of FLU associated with the $6 \mu \mathrm{m}$ beads (F6) was estimated based on (i) the results of the quantity of FLU associated to $2 \mu \mathrm{m}$ beads (F2) and (ii) polymer volume ratio calculations between the $2 \mu \mathrm{m}$ and $6 \mu \mathrm{m}$ micro-PS. The quantity 
of FLU associated to the algae $(\mathrm{Fa})$ was calculated by subtracting the estimated quantity of FLU associated to the $6 \mu \mathrm{m}$ beads (F6) to the quantity of FLU measured in the pellet (Fp). Partition coefficients $\mathrm{Kp}\left(\mathrm{L} \mathrm{Kg}^{-1}\right)$ for algae (KpA) and micro-PS (KpMPS) were calculated by dividing the quantity of FLU in $\mu \mathrm{g} / \mathrm{kg}$ associated to algae or micro-PS ( 2 and $6 \mu \mathrm{m})$ by the aqueous phase concentration $(\mu \mathrm{g} / \mathrm{L})$.

4. Mussel sampling

Mussels were sampled at the end of each phase $($ exposure $=\mathrm{T} 7$; depuration $=\mathrm{T} 14)$. A total of 21 mussels were collected per condition: 9 mussels ( 3 mussels per replicate tank) were collected for histology and histopathology analyses; 12 mussels (4 mussels per replicate tank) were collected for hemolymph sampling, FLU quantification, gene expression and enzyme activity. Hemolymph was withdrawn from the adductor muscle using a 1-ml hypodermic syringe ( $25 \mathrm{G}$ needle) before being filtered on $80 \mu \mathrm{m}$ nylon mesh and kept on ice until flow cytometric analyses. The digestive gland and gills of the same animals were dissected in RNase-free conditions, snap-frozen in liquid nitrogen, crushed to a fine powder at $-196^{\circ} \mathrm{C}$ with a mixer mill MM400 (Retsch) and stored at $-80^{\circ} \mathrm{C}$ until RNA extraction, enzymatic assays and FLU quantification. For histological observations, a cross section of mussel tissues (including digestive gland, gills, mantle and gonad) was fixed in modified Davidson's solution (Latendresse et al., 2002) for $48 \mathrm{~h}$ and further processed as described in Fabioux et al. (2005). Microscopic observations were performed in order to localize the micro-PS in tissues. A five-level semiquantitative scale was established to assess the intensity of histopathological conditions.

\section{Fluoranthene quantification}

FLU was quantified in digestive gland using a Stir Bar Sorptive Extraction-Thermal DesorptionGas Chromatography-Mass Spectrometry (SBSE-TD-GC-MS) method described in Lacroix et al. (2014b). FLU was quantified relatively to [2H10]-FLU using a calibration curve ranging from 1 ng to $10 \mu \mathrm{g}$ per bar. The limit of quantification (LOQ) was $0.2 \mu \mathrm{g} \mathrm{g}^{-1}$ wet weight (WW). Results of 
fluoranthene content in whole mussel and digestive gland were expressed as $\mu \mathrm{g}$ FLU g ${ }^{-1}$ wet tissue weight (WW).
6. Flow cytometric analyses

Morphological and functional analyses of collected hemocytes were performed on a BD FACSverse flow cytometer (BD Biosciences, France).Hemocyte mortality was assessed according to Haberkorn et al. (2010) and expressed as the percentage of dead cells present in each sample. The concentration of circulating hemocytes (all hemocytes, granulocytes and hyalinocytes) was also determined. Phagocytosis activity was calculated as the percentage of hemocytes that ingested three fluorescent beads or more (=active hemocytes), while phagocytosis capacity was estimated as the average number of beads engulfed by active hemocytes (Hégaret et al., 2003). ROS production was measured using a DCFH-DA assay as described in Lambert et al. (2003) and was expressed as the mean geometric fluorescence (in arbitrary units, A.U.).

6. Antioxidant enzyme activities

An aliquot of $50 \mathrm{mg}$ of grounded digestive gland was homogenized (1:4,w/v) in K-phosphate buffer $100 \mathrm{mM}$, pH 7.6 containing $0.15 \mathrm{M} \mathrm{KCl}, 1 \mathrm{mM}$ DTT and $1 \mathrm{mM}$ EDTA in a sonicator UP 200S ( 0.5 cycle and $60 \%$ of amplitude with two rounds of 5 pulses). Samples were then centrifuged at $10.000 \mathrm{xg}$ for $20 \mathrm{~min}\left(4^{\circ} \mathrm{C}\right)$. Supernatants were used for all enzymatic assays as well as protein quantification according to Lowry et al. (1951) by using bovine serum albumin as standard. Superoxide-dismutase (SOD) was measured using SOD-Assay kit-WST and was expressed in $\mathrm{U} \mathrm{min}^{-1} \mathrm{mg}_{\text {protein }}{ }^{-1}$. Catalase (CAT) was measured according to Claiborne (1985) and expressed as $\mu \mathrm{mol}$ of $\mathrm{H}_{2} \mathrm{O}_{2}$ consumed $\mathrm{min}^{-1} \mathrm{mg}^{-1}$ protein. Glutathione reductase (GR) activity was measured according to Ramos-Martinez et al. (1983) and expressed as nmol of NADPH oxidized $\min ^{-1} \mathrm{mg}^{-1}$ protein. Glutathione S-transferase (GST) was measured according to Habig et al. (1974) and was expressed as nmol $\mathrm{min}^{-1} \mathrm{mg}_{\text {protein }}{ }^{-1}$. Lipid peroxidation (LPO) was quantified following Buege and Aust (1978) and expressed as nmol MDA mg protein ${ }^{-1}$. 
245

An aliquot of $50 \mathrm{mg}$ of grounded tissue was homogenized in $0.5 \mathrm{ml}$ of Tri Reagent (Ambion) using a Precellys ${ }^{\circledR} 24$ grinder coupled to a Cryolys ${ }^{\circledR}$ cooling system (Bertin technologies) for total RNA extraction. An aliquot of $40 \mu \mathrm{g}$ RNA was then treated with the RTS DNase ${ }^{\mathrm{TM}} \mathrm{Kit}(1 \mathrm{U} / 3 \mu \mathrm{g}$ total RNA, Mo Bio). RNA purity and concentration were measured using a Nanodrop spectrophotometer (Thermo Scientific) and RNA integrity was assessed using RNA nanochips and Agilent RNA 6000 nanoreagents (Agilent Technologies).RNA Integrity Numbers (RIN) were 8.3 \pm 1.0 and $6.6 \pm 0.6$ (mean \pm standard deviation) for gills and digestive gland samples, respectively. $2.5 \mu \mathrm{g}$ RNA were reverse-transcribed using the RevertAidTM H Minus First Strand cDNA Synthesis Kit (Fermentas) with random hexamers. A "reference" cDNA sample was made by pooling the same volume of $10 \mathrm{cDNA}$ samples produced similarly from 10 mussels sampled at the end of the acclimation.

\subsection{Real-time quantitative PCR}

Real-time PCR was performed using a LightCycler ${ }^{\circledR} 480$ II (Roche) for 18 target genes and 5 potential reference genes in gills and digestive gland of each individual. Primer pairs and amplicon characteristics (primer sequence, efficiency, product length and melting temperature) are listed in Table 1. Assays were performed in triplicate according to the protocol described by Lacroix et al. (2014a).PCR efficiency (E) was determined for each primer pair by performing standard curves from serial dilutions. Each PCR run included positive (reference cDNA sample) and negative (MilliQ water) controls. For each sample, absence of DNA contamination after DNase treatment was assessed by negative reverse-transcription controls on total RNA samples. PCR analysis was performed following "MIQE precis guidelines" (Bustin et al., 2009). The stability of several reference genes (ef1 $\alpha, e f 2, r p l 7, \alpha t u b$ and $28 s r R N A)$ was assessed using the excel-based Normfinder software (Norman et al., 2004). Results indicated efl $\alpha, r p l 7$ and $\alpha t u b$ were the most stable genes in gills (lowest stability value of $0.241,0.286$ and 0.239 , respectively) and in digestive gland (lowest stability value of $0.174,0.139$ and 0.179 , respectively) among the 
conditions. The geometric mean of these three genes was therefore used as an index to normalize target gene expression. The normalization index exhibited a stability value of 0.109 and 0.056 in gills and digestive gland, respectively. Target gene relative expression ratios $(\mathrm{R})$ were expressed according to the Pfaffl formula (Pfaffl, 2001):

$$
R=\frac{E f f_{\text {Target }}\left(\Delta \mathrm{Cq}_{\text {Target }}(\text { reference-sample })\right)}{E f f_{\text {Index }}\left(\Delta \mathrm{Cq}_{\text {Index }}(\text { reference-sample })\right)}
$$

\section{Statistical analyses}

All quantitative variables were analyzed using a two-way ANOVA in order to determine possible interactive effects between the two independent variables called factors (microplastics and fluoranthene) on each parameter that constitutes the dependent variable (Sokal and Rohlf, 1981). Normality was assumed and homogeneity of variance was verified with Cochran's test (data were $\log 10$ transformed when homogeneity of variance was not achieved). Percentages of phagocytic and of dead hemocytes were arcsin transformed to meet homogeneity requirements. Intensities of histopathological conditions (semi-quantitative data) were compared statistically using the MannWhitney U-test to assess differences attributable to the conditions (micro-PS, FLU or the combination of both) after exposure and depuration periods. All tests were performed using the STATISTICA 10 software for Windows.

\section{Results}

1. Fluoranthene partition in algal cultures

No difference was observed between $45 \mathrm{~min}$ and $5 \mathrm{~h}$ in the quantity of FLU measured in each fraction (F2, Fd and Fp) suggesting that sorption equilibrium occurred. In the FLU condition (i.e. no micro-PS added in the algal culture), fluoranthene was mainly associated with algae (89\%) in comparison with the fraction of FLU dissolved in water (11\%) (Table 2). Algae exhibited a Log KpA of 4.84. In micro-PS+FLU condition, the fraction of FLU dissolved in water was similar (12\%) but the fraction of FLU associated to algae was reduced (67\%) and a significant fraction of 
FLU appeared associated to the micro-PS (21\%). This is reflected by a higher Log KpMPS (6.58)

294 in comparison with Log KpA (4.77) (Table 2).

295

296

297

2. Fluoranthene quantification in mussel tissues

At T7, mussels exposed to FLU alone or micro-PS+FLU showed similar concentrations of FLU in gills $\left(12.1 \pm 0.8 \mu \mathrm{g} \mathrm{g}^{-1}\right.$ and $13.5 \pm 1.1 \mu \mathrm{g} \mathrm{g}{ }^{-1}$, mean $\pm \mathrm{SE}$, respectively) and digestive gland (117.1 $\pm 10.7 \mu \mathrm{g} \mathrm{g}^{-1}$ and $89.2 \pm 8.4 \mu \mathrm{g} \mathrm{g}^{-1}$, mean $\pm \mathrm{SE}$, respectively) $(\mathrm{p}>0.05$; Figure 1$)$. Negligible amounts of FLU $\left(<2 \mu \mathrm{g} \mathrm{g}^{-1}\right)$ were detected in tissues of control and micro-PS exposed mussels. At T14, FLU concentration in gills was similar in mussels exposed to FLU alone or micro-PS+FLU $\left(4.5 \pm 0.5 \mu \mathrm{g} \mathrm{g}^{-1}\right.$ and $6.2 \pm 0.7 \mu \mathrm{g} \mathrm{g}^{-1}$, respectively) (Figure 1). In digestive glands, the concentration of FLU was significantly lower in mussels exposed to FLU alone $\left(36.9 \pm 6.7 \mu \mathrm{g} \mathrm{g}^{-1}\right.$, mean $\pm \mathrm{SE})$ than in mussels exposed to micro-PS+FLU $\left(61.3 \pm 4.8 \mu \mathrm{g} \mathrm{g}^{-1}\right.$, mean $\left.\pm \mathrm{SE}\right)(\mathrm{p}<0.001$; Figure 1). No FLU was detected in tissues of control and micro-PS exposed mussels.

\section{Histology and histopathology}

At T7, micro-PS were detected exclusively inside the digestive tract and the intestine of all mussels exposed to micro-PS, regardless of the exposure to FLU (Figure 2A).At T14, some microbeads were still observed in the intestine of mussels exposed to micro-PS and microPS+FLU ( $<1-5$ beads/histological section/animal). A few micro-PS were also observed stuck in the mucus on the outer side of the gills epithelium (Figure 2B). There was no observation of micro-PS in any other tissue.

At T7, a significant increase in total histopathological lesions/abnormalities was demonstrated in mussels exposed to FLU, micro-PS and Micro-PS+FLU, in comparison with controls (Figure 3). Significantly higher hemocyte infiltration and ceroids (stress induced lipofuscin-pigments) were observed in the stomach and digestive gland of all mussels exposed to FLU in comparison to mussels exposed to micro-PS alone (Figures 2C-F, 3). At T14, significantly higher histopathological lesions/abnormalities were observed in mussels exposed to micro-PS+FLU, in comparison with all other treatments (Figure 3). This difference was mainly driven by higher 
hemocyte infiltration and ceroids detected in gills, gonads, digestive glands and intestine of microPS+FLU exposed mussels.

After seven days of exposure, the percentage of dead hemocytes increased significantly in mussels exposed to micro-PS and FLU, alone or in combination, in comparison with controls (Figure 4A, Table 3). ROS production was significantly higher in mussels exposed to micro-PS and FLU alone, in comparison with control individuals and mussels exposed to micro-PS+FLU (Figure 4B, Table 3). Significant interactions between both stressors were demonstrated on percentage of dead hemocytes, phagocytosis capacity and ROS production (Figure 4, Table 3). No effect of micro-PS and FLU alone or in combination was observed on phagocytosis activity and hemocyte concentration at that time.

At the end of the depuration, the percentage of dead hemocytes remained significantly higher in mussels exposed to micro-PS and FLU, in single or in combination, in comparison with controls (Figure 4A, Table 3). All micro-PS exposed mussels exhibited significantly lower granulocyte concentration $\left(1.2 \pm 0.210^{5}\right.$ cells $\mathrm{mL}^{-1}$ and $1.1 \pm 0.210^{5}$ cells $\mathrm{mL}^{-1}$ for mussels exposed to microPS and micro-PS+FLU, respectively) in comparison with controls $\left(3.4 \pm 0.510^{5}\right.$ cells $\left.\mathrm{mL}^{-1}\right)$ and mussels exposed to FLU $\left(2.7 \pm 0.510^{5}\right.$ cells $\left.\mathrm{mL}^{-1}\right)$ (Table 3$)$. This decrease was also reflected in the total hemocyte count with mean cells concentrations of $5.4 \pm 1.110^{5}$ cells mL $^{-1}, 4.8 \pm 0.810^{5}$ cells $\mathrm{mL}^{-1}, 2.8 \pm 0.510^{5}$ cells $\mathrm{mL}^{-1}$ and $2.3 \pm 0.410^{5}$ cells $\mathrm{mL}^{-1}$ in controls and mussels exposed to FLU, micro-PS and micro-PS+FLU, respectively (Table 3). All micro-PS exposed mussels demonstrated significantly higher phagocytosis capacity as compared to control individuals (Figure 4B, Table 3). No effect of micro-PS and FLU alone or in combination was observed on phagocytosis activity, ROS production and hyalinocyte concentration at that time. activity in mussels exposed to micro-PS and micro-PS+FLU $\left(52.6 \pm 3.9\right.$ and $66.6 \pm 8.7 \mu \mathrm{mol} \mathrm{min}{ }^{-1}$ 
$\mathrm{mg}^{-1}$, respectively) in comparison with controls and mussels exposed to FLU alone $(70.4 \pm 7.1$

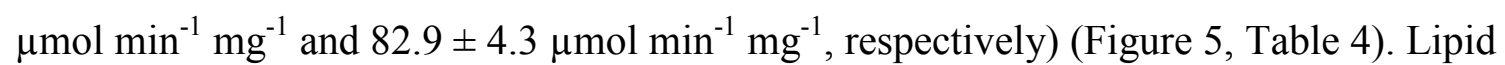
peroxidation (LPO) was also significantly reduced in mussels exposed to micro-PS alone or in combination with FLU $\left(0.9 \pm 0.2\right.$ and $1.1 \pm 0.2 \mathrm{TBARS} \mathrm{mg}^{-1}$, respectively) compared to controls $\left(1.4 \pm 0.2 \mathrm{TBARS} \mathrm{mg}^{-1}\right)$ and mussels exposed to FLU alone $\left(1.8 \pm 0.1 \mathrm{TBARS} \mathrm{mg}^{-1}\right)$ (Figure 5, Table 4). Activities of GR and SOD were significantly higher in mussels exposed to FLU (17.1 \pm $1.7 \mathrm{nmol} \mathrm{min}^{-1} \mathrm{mg}^{-1}$ and $61.1 \pm 4.8 \mathrm{U} \mathrm{min}^{-1} \mathrm{mg}^{-1}$, mean $\pm \mathrm{SE}$, respectively) compared to control mussels (9.6 $\pm 0.4 \mathrm{nmol} \mathrm{min} \mathrm{mg}^{-1}$ and $47.0 \pm 2.3 \mathrm{U} \mathrm{min}^{-1} \mathrm{mg}^{-1}$, respectively) (Figure 5, Table 4). At T14, significant effects of micro-PS and FLU exposures were observed on GST and SOD, with an increase of enzyme activities in all exposed mussels. Highest GST and SOD activities (16.9 \pm $1.4 \mathrm{nmol} \mathrm{min} \mathrm{mg}^{-1}$ and $50.7 \pm 3.5 \mathrm{U} \mathrm{min}^{-1} \mathrm{mg}^{-1}$, mean $\pm \mathrm{SE}$, respectively) were observed in the micro-PS+FLU condition in comparison with all other treatments (Figure 5, Table 4). Significant effects of micro-PS were observed on LPO levels with the lowest concentration being measured in micro-PS+FLU exposed mussels (Figure 5, Table 4). A significant interaction between micro-PS and FLU was observed on the activity of the GR: FLU exposure led to a decrease in GR activity in the absence of micro-PS $\left(12.0 \pm 0.5 \mathrm{nmol} \mathrm{min}{ }^{-1} \mathrm{mg}^{-1} v s .10 .7 \pm 0.9 \mathrm{nmol} \mathrm{min}^{-1} \mathrm{mg}^{-1}\right.$, in control and FLU exposed mussels, respectively), while a significantly higher activity was observed in microPS+FLU exposed mussels $\left(12.8 \pm 0.8 \mathrm{nmol} \mathrm{min}^{-1} \mathrm{mg}^{-1}\right)$ in comparison with micro-PS exposed

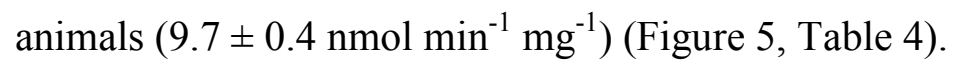

\section{Gene expression}

At T7, significant effects of micro-PS were observed in mRNA levels only in gills. Compared to controls, mRNA level of lys increased 2.2 and 1.2 folds, respectively in micro-PS and microPS+FLU exposed mussels; the mRNA levels of cat were 0.7 and 0.8 times lower, respectively in micro-PS and micro-PS+FLU exposed mussels (Table 5). At T14 in gills, exposure to micro-PS led to a significant increase in mRNA level for $p k$ by 1.1 and 1.4 times in mussels exposed to micro-PS and micro-PS+FLU, respectively, compared to controls (Table 6). The mRNA level of 
sod increased significantly by $1.1,1.2$ and 1.5 times in mussels exposed to FLU, micro-PS and

micro-PS+FLU, respectively, compared to controls. The mRNA levels of gpx and idp genes were significantly higher in gills of mussels exposed to FLU alone (by 2.3 and 2.4 times, respectively) or in combination with micro-PS (by 2.7 and 2.6 times, respectively) in comparison with controls (Tables 5, 6). A significant interaction between both factors (micro-PS and FLU) was observed on cat mRNA level in gills: micro-PS and FLU single exposures led to a reduction by 0.9 and 0.7 times, respectively, in comparison with controls, while exposure to micro-PS+FLU induced an increase of cat mRNA level by 1.2 times compared to controls (Table 5). The mRNA levels of $p k$, sod and cat genes were systematically highest in the mussels exposed to micro-PS+FLU, compared to the 3 other conditions. At T14 in digestive gland, micro-PS exposure induced a significant decrease of pgp mRNA level by 0.4 and 0.7 in mussels exposed to micro-PS and micro-PS+FLU, respectively, compared to controls (Tables 5, 6). A significant interaction between both factors was observed for cat mRNA level: micro-PS and FLU single exposures led to a reduction by 0.7 and 0.8 times, respectively, in comparison with controls, while the double exposure micro-PS+FLU induced an increase of mRNA level by 1.7 times compared to controls (Table 5). In addition, the mRNA levels of amylase, pk and sod were significantly higher by 1.6, 1.2 and 1.5 times respectively in mussels exposed to FLU compared to controls, with highest inductions observed in mussels exposed to micro-PS+FLU (3.2, 1.5 and 1.7 times, respectively) (Tables 5,6). Exposure to FLU induced a diminution of $\sigma$ gst mRNA level by 0.7 times in comparison with controls. Overall the experiment, no effects of micro-PS or FLU or their combination were observed on cyp 11, cyp32, wgst, $\mu$ gst, gadd45a, gapdh, hk, p53, casp37-3 mRNA levels.

\section{Discussion}

\section{Micro-PS exhibited high sorption capacity for fluoranthene}

The present study evidenced that micro-PS exhibited higher sorption capacity for fluoranthene than marine algae C. muelleri as indicated by the partition coefficient log Kp values, and this confirmed a strong affinity of fluoranthene for polystyrene, especially when considering the 
relative mass proportion of algae and micro-PS fed to the mussels (289:1) in the context of our study. Polyethylene (PE) and polyvinylchloride (PVC) also demonstrated high sorption capacity, as expressed with Log Kp values, for phenanthrene and dichlorodiphenyltrichloroethane (DDT) (Bakir et al., 2012). Similarly, polystyrene (PS) and PE microparticles exhibited high sorption capacity for pyrene (Avio et al., 2015), and polypropylene (PP) pellets immersed in Tokyo Bay also showed high adsorption coefficients for polychlorobiphenyls (PCB) and dichlorodiphenyltrichloroethane (DDE) (Mato et al., 2001). However, as some sediment and suspended particles may exhibit similar or even higher adsorption coefficient than microplastics (Mato et al., 2001; Velzeboer et al., 2014), it may be reasonable to question the respective role of each component in the contamination of marine organisms.

\section{Micro-PS had negligible effect on fluoranthene bioaccumulation but altered its depuration}

\section{in marine mussels}

The similar fluoranthene bioaccumulation in all exposed mussels at $\mathrm{T} 7$ may be explained by the fact that all FLU fractions (on algae, on micro-PS and dissolved in water) were available for mussels. This actually shows that the Trojan horse effect of micro-PS (i.e. facilitating the uptake of organic contaminants by marine organisms) was negligible in the context of our study as to compare to water and food exposures, especially given the low proportion of micro-PS relatively to microalgae. This is in agreement with a recent study that critically reviewed all available data regarding this hypothesis (field, laboratory and modelling studies) and concluded that given the low abundance of plastic particles relative to other media present in the oceans (marine phytoplankton in our case), exposure to POP via plastic is likely to be negligible compared to natural pathways (Koelmans et al., 2016).

At the end of the depuration phase, the highest FLU concentrations measured in the digestive glands of micro-PS+FLU exposed mussels may be related to (i) some loaded micro-PS remaining in mussels tissues; (ii) a time lag in the kinetics of FLU desorption/assimilation from micro-PS that were not assimilated as the micro-algae were; (iii) an indirect effect of micro-PS exposure on 
the general metabolism of mussels resulting in a reduction in FLU depuration. Indeed, low metabolism and activity are associated with low PAH clearance rates (Lotufo et al., 1998; AlSubiai et al., 2012)); and (iv) a possible direct impact of micro-PS on PAH detoxification processes, as suggested by a decrease in P-glycoprotein mRNA levels in all mussels exposed to micro-PS. Indeed, P-glycoproteins are transmembrane proteins primarily involved in the efflux of a wide range of compounds including unmodified xenobiotics and PAH (Smital et al., 2003). Impacts of polyethylene microbeads on detoxification mechanisms were previously demonstrated in common goby Pomatoschistus microps juveniles and seabass Dicentrarchus labrax larvae (Mazurais et al., 2015; Oliveira et al., 2013). The high fluoranthene concentration remaining in tissues of mussels exposed to micro-PS and FLU at the end of the depuration may explain the highest levels of ceroids, hemocyte infiltration and tissue lesions, known to be associated with PAH (Kim et al., 2008; Al-Subiai et al., 2012), observed in this condition.

\section{Micro-PS exposure affected mussels physiology}

\section{Modulation of digestion and energy metabolism}

The induction of glycolysis and digestive activity upon micro-PS exposure may sign increased energy requirements in response to the implementation of anti-oxidant and detoxification processes (Palais et al., 2010). This mechanism would allow the animal to cope with experimental stress and maintain homeostasis, as suggested in a study conducted by Van Cauwenberghe et al.(2015) who demonstrated a $25 \%$ increase in energy consumption in mussels exposed to microPS for 14 days in comparison with controls. Alternatively, the increase in digestive activity could be explained by a compensatory effect on food intake and enhancement of mechanical digestion upon particles exposure, as also hypothesized in oysters (Sussarellu et al., 2016). An increase in absorption efficiency was for instance demonstrated in mussels exposed to moderate quantities of silt in relation to an improvement of the mechanical disruption in the stomach due to the presence of particles (Bayne et al., 1987). In the present study, a control condition using non-plastic inorganic particles of same size (silt, clay, silica) is lacking to discriminate whether the overall 
observed effects of micro-PS were due to the plastic nature of the particles or to the particles as such. This point should be addressed in further experiments.

\section{Modulation of anti-oxidant defences and oxidative damages}

Micro-PS exposure alone significantly modulated the cell oxidative system in our study. Such perturbations were also observed in mussels exposed to polystyrene (PS) and polyethylene (PE) alone or in combination with pyrene (Avio et al., 2015). Reactive oxygen species (ROS) production in hemocytes is naturally occurring (Galloway and Depledge, 2001) but overproduction of ROS may lead to oxidative damages (Lesser, 2006). In our study, the significant rise of ROS in hemocytes upon 7 days of micro-PS exposure seemed to have been well controlled as no anti-oxidant markers were activated and no sign of lipid peroxidation (LPO) was observed at that time. A biphasic response of the catalase involved in the neutralization of the hydrogen peroxide $\left(\mathrm{H}_{2} \mathrm{O}_{2}\right)$ is hypothesized with a possible activation within the first days of exposure and consequently followed by a decrease in gene expression and protein activity afterwards (T7). Such compensatory effect was previously observed in eels and mussels (Regoli et al., 2011; Romeo et al., 2003). Also, implication of other enzymes involved in $\mathrm{H}_{2} \mathrm{O}_{2}$ neutralization such as glutathione peroxidase (GPX) cannot be yet clarified. After depuration, the SOD activity in micro-PS exposed mussels reflected the need for a greater capacity to rapidly convert $\mathrm{O}_{2}{ }^{-}$into the less damaging hydrogen peroxide $\left(\mathrm{H}_{2} \mathrm{O}_{2}\right)$, thus contributing to prevent host cellular oxidative damage (Jo et al., 2008). In the micro-PS+FLU exposed mussels, an efficient neutralization of the ROS is suggested by the activation of anti-oxidant and glutathione related markers and low LPO levels. Low LPO levels suggesting a suitable neutralization of ROS was previously hypothesized in the crustacean Carcinus maenas (Rodrigues et al., 2013), and the molluscs Perna viridis (Cheung et al., 2001) and Chlamys farreri (Xiu et al., 2014) exposed to FLU.

\section{Modulation of hemocytes mortality and activities}

Micro-PS exposure impaired major hemocyte parameters. Based on the absence of observed translocation, direct toxicity due to contact with micro-PS or leaching of chemicals were excluded 
to explain the high percentage of dead hemocytes in micro-PS exposed mussels. Instead, this may

477 result from a modification of the circulating hemocyte concentration or balance in hemolymph.

478 For instance, the recruitment of active hemocytes for incursion in tissues could explain the

479 decrease in circulating granulocyte and total hemocyte concentrations observed in micro-PS

480 exposed mussels, which would subsequently modify the balance of live circulating hemocytes in

481 the hemolymph (Hégaret et al., 2007). Modulation of mussel immunity was also demonstrated

482 through the increase in lys mRNA levels in gills of mussels exposed to micro-PS, related either to

483 (i) a direct effect of micro-PS, as demonstrated for a wide range of pollutants including metals,

484 hydrocarbons, carbon nanoparticles, oestrogenic compounds (Renault, 2015), polyethylene beads

485 (Von moos et al., 2012) and styrene monomers (Mamaca et al., 2005); or to (ii) an increase of the

486 digestive activity observed in the present study, as most lysozymes are known to play a dual role

487 in bivalve immunity and digestion of microbial food particles (Allam and Raftos, 2015). Finally,

488 the absence of clear effects of micro-PS exposure on phagocytosis is consistent with the study

489 conducted by Browne et al. (2008). However, statistically significant interactions between both

490 stressors suggest a potential modification of the bioavailability or toxicity of FLU by micro-PS.

491 Indeed, intracellular distribution, and toxicity of fluoranthene carried by algae and micro-PS may

492 have been quite different due to the nature and the assimilation or not of the carrier. Hemocytes of

493 bivalves are not restricted to immune processes and are involved in many other physiological

494 functions including nutrient transport and digestion, tissue and shell formation, detoxification and

495 maintenance of homeostasis (Donaghy et al., 2009). Therefore, the impact of micro-PS on

496 hemocyte activities should be considered in a larger context than immune responses, i.e. at the

497 whole animal homeostasis and longer-term studies are needed to clarify the chronic effect of

498 microplastics exposure in real environmental conditions.

\section{Conclusion}

500 Despite a high sorption of fluoranthene on micro-PS, this did not enhance fluoranthene 
exposed to fluoranthene via water and micro-algae. Micro-PS concentration used in this study $\left(0.032 \mathrm{mg} \mathrm{L}^{-1}\right)$ was lower than those used in most studies on marine invertebrates (range 0.8 to $2500 \mathrm{mg} \mathrm{L}^{-1}$ ) (Avio et al., 2015; Besseling et al., 2013; Wegner et al., 2012; Von Moos et al., 2012) and was in the range of the highest estimated field concentration (most exclusively for particles $>330 \mu \mathrm{m}$ ) based on the assumption of a steady fragmentation of plastic debris as detailed in Sussarellu et al. (2016). This, in addition with recent published papers and reports (GESAMP, 2015; Herzke et al., 2016; Koelmans et al., 2016) suggest that given the current microplastics concentration in oceans the bioaccumulation of POP from microplastics is likely to be minor in regards with uptake via natural pathways (waterborne and foodborne contamination).

Nevertheless, marine plastic litter is expected to increase over the next decades, leading to ever increasing microplastic pollution in oceans, and the concentrations below which no effect can be seen on POP bioaccumulation could locally be exceeded.

Despite no effect observed on fluoranthene bioaccumulation, the ingestion of contaminated microPS may have modified bioavailability and fluoranthene kinetics in mussel tissues due to the nature and the assimilation or not of the carrier (algae $v s$. plastic). This was suggested by a reduction in the fluoranthene depuration and significant interactions between micro-PS and fluoranthene observed on some cellular and molecular biomarkers. It is noteworthy that the bioformation of fluoranthene metabolites upon micro-PS exposure were not investigated in the present study. This aspect should be considered in further experiments as it could potentially have contributed to the additional and interactive effects observed in micro-PS+FLU exposed mussels. Finally, micro-PS alone triggered substantial modulation of cellular oxidative balance, an increase in histopathological damages, percentage of dead hemocytes and lysozyme mRNA levels, which suggested an impairment of the bivalve metabolism upon micro-PS exposure. As the toxic endpoints highlighted here were observed in specific and restrictive experimental conditions, the energetic costs to the animals (in terms of maintenance costs, immune responses, detoxification and oxidative balance regulation) must be further evaluated in the context of in situ exposure 
and/or experimental studies that more closely mimic complex in situ conditions, in particular by using different particulate matter and chemical mixtures representative of those found in the field.

\section{Acknowledgements}

This study was partly funded by the MICRO EU Interreg-funded project (MICRO 09-002-BE).

The authors are grateful to M. Van der Meulen, L. Devriese, D. Vethaak, T. Maes, and D.

Mazurais for their valuable support and helpful discussions and also the anonymous reviewers of the paper who greatly helped improving the scientific quality of the manuscript. We also thank $\operatorname{Pr}$

R. Whittington for his helpful revision of the English and his comments on the manuscript.

\section{References}

Al-Subiai, S.N., Arlt, V.M., Frickers, P.E., Readman, J.W., Stolpe, B., Lead, J.R., Moody, A.J., Jha, A.N., 2012. Merging nano-genotoxicology with eco-genotoxicology: An integrated approach to determine interactive genotoxic and sub-lethal toxic effects of C60 fullerenes and fluoranthene in marine mussels, Mytilus sp. Mutat. Res. Toxicol. Environ. Mutagen., 745, 92-103. doi:10.1016/j.mrgentox.2011.12.019

Andrady, A.L., 2011. Microplastics in the marine environment. Mar. Pollut. Bull. 62, 1596-1605. doi:10.1016/j.marpolbul.2011.05.030

Avio, C.G., Gorbi, S., Milan, M., Benedetti, M., Fattorini, D., d' Errico, G., Pauletto, M., Bargelloni, L., Regoli, F., 2015. Pollutants bioavailability and toxicological risk from microplastics to marine mussels.Environ. Pollut. 198, 211-222. doi:10.1016/j.envpol.2014.12.021

Bakir, A., Rowland, S.J., Thompson, R.C., 2014. Enhanced desorption of persistent organic pollutants from microplastics under simulated physiological conditions. Environ. Pollut. 185, 16-23. doi:10.1016/j.envpol.2013.10.007

Bassim, S., Genard, B., Gauthier-Clerc, S., Moraga, D., Tremblay, R., 2014. Ontogeny of bivalve immunity: assessing the potential of next-generation sequencingtechniques. Rev. Aquaculture 6, 1-21.

Baumard, P., Budzinski, H., Garrigues, P., Sorbe, J.C., Burgeot, T., Bellocq, J., 1998. Concentrations of PAHs (polycyclic aromatic hydrocarbons) in various marine organisms in relation to those in sediments and to trophic level. Mar. Pollut. Bull. 36, 951-960. doi:10.1016/S0025-326X(98)00088-5

Bayne, B. L., Hawkins, A. J. S., and Navarro, E., 1987. Feeding and digestion by the mussel Mytilus edulis L. (Bivalvia: Mollusca) in mixtures of silt and algal cells at low concentrations. J. Exp. Mar. Bio. Ecol. 111, 1-22. 
Besseling, E., Wegner, A., Foekema, E.M., van den Heuvel-Greve, M.J., Koelmans, A.A., 2013. Effects of Microplastic on Fitness and PCB Bioaccumulation by the Lugworm Arenicola marina (L.).Environ. Sci. Technol. 47, 593-600. doi:10.1021/es302763x

Bierne, N., Borsa, P., Daguin, C., Jollivet, D., Viard, F., Bonhomme, F., David, P., 2003. Introgression patterns in the mosaic hybrid zone between Mytilus edulis and $M$. galloprovincialis. Mol. Ecol. 12, 447-461. doi:10.1046/j.1365-294X.2003.01730.x

Bouzas, A., Aguado, D., Martí, N., Pastor, J.M., Herráez, R., Campins, P., Seco, A., 2011. Alkylphenols and polycyclic aromatic hydrocarbons in eastern Mediterranean Spanish coastal marine bivalves. Environ. Monit. Assess. 176, 169-181. doi:10.1007/s10661-010$1574-5$

Browne, M.A., Dissanayake, A., Galloway, T.S., Lowe, D.M., Thompson, R.C., 2008. Ingested Microscopic Plastic Translocates to the Circulatory System of the Mussel, Mytilus edulis (L.).Environ. Sci. Technol. 42, 5026-5031. doi:10.1021/es800249a

Buege, J.A., Aust, S.D., 1978. Microsomal lipid peroxidation, in: Packer, S.F. and L. (Ed.), Methods in Enzymology, Biomembranes - Part C: Biological Oxidations. Academic Press, pp. 302-310.

Bustin, S.A., Benes, V., Garson, J.A., Hellemans, J., Huggett, J., Kubista, M., Mueller, R., Nolan, T., Pfaffl, M.W., Shipley, G.L., Vandesompele, J., Wittwer, C.T., 2009. The MIQE guidelines: Minimum information for publication of quantitative real-time PCR experiments. Clin. Chem. 55, 611-622.

Carpenter, E.J., Smith, K.L., 1972.Plastics on the Sargasso Sea Surface. Science 175, 1240-1241. doi:10.1126/science.175.4027.1240

Cheung, C.C.C., Zheng, G.J., Li, A.M.Y., Richardson, B.J., Lam, P.K.S., 2001. Relationships between tissue concentrations of polycyclic aromatic hydrocarbons and antioxidative responses of marine mussels, Pernaviridis.Aquat.Toxicol. 52, 189-203. doi:10.1016/S0166$445 \mathrm{X}(00) 00145-4$

Claiborne, A., 1985. Catalase activity. In: Handbook of Methods for Oxygene Radical Research. GREENWALD RA (ed), CRC Press, Boca Raton, FL, pp 283-284.

Cole, M., Lindeque, P., Halsband, C., Galloway, T.S., 2011. Microplastics as contaminants in the marine environment: A review. Mar. Pollut. Bull. 62, 2588-2597. doi:10.1016/j.marpolbul.2011.09.025

Donaghy, L., Lambert, C., Choi, K.-S., Soudant, P., 2009. Hemocytes of the carpet shell clam (Ruditapesdecussatus) and the Manila clam (Ruditapesphilippinarum): Current knowledge and future prospects. Aquaculture 297, 10-24. doi:10.1016/j.aquaculture.2009.09.003

Eriksen, M., Lebreton, L.C.M., Carson, H.S., Thiel, M., Moore, C.J., Borerro, J.C., Galgani, F., Ryan, P.G., Reisser, J., 2014. Plastic Pollution in the World's Oceans: More than 5 Trillion Plastic Pieces Weighing over 250,000 Tons Afloat at Sea. PLoS ONE 9, e111913. doi:10.1371/journal.pone.0111913

Fabioux, C., Huvet, A., Le Souchu, P., Le Pennec, M., Pouvreau, S., 2005. Temperature and photoperiod drive Crassostrea gigas reproductive internal clock. Aquaculture 250, 458-470. doi:10.1016/j.aquaculture.2005.02.038

Filella, M. (2015). Questions of size and numbers in environmental research on microplastics: methodological and conceptual aspects. Environ. Chem. 12:527. 
Galloway, T.S., Depledge, M.H., 2001. Immunotoxicity in invertebrates: Measurement and ecotoxicological relevance. Ecotoxicology 10, 5-23.

GESAMP. Sources, fate and effects of microplastics in the marine environment: a global assessment. Kershaw, P. J., (ed.). (IMO/FAO/UNESCO-IOC/UNIDO/WMO/IAEA/UN/UNEP/UNDP Joint Group of Experts on the Scientific Aspects of Marine Environmental Protection). Rep. Stud. 2015, GESAMP No. 90, 96 p.

Haberkorn, H., Lambert, C., Le Goïc, N., Guéguen, M., Moal, J., Palacios, E., Lassus, P., Soudant, P., 2010. Effects of Alexandriumminutum exposure upon physiological and hematological variables of diploid and triploid oysters, Crassostrea gigas.Aquat.Toxicol. 97, 96-108. doi:10.1016/j.aquatox.2009.12.006

Habig, W.H., Pabst, M.J., Jakoby, W.B., 1974. Glutathione S-Transferases the first enzymatic step in mercapturic acid formation. J. Biol. Chem. 249, 7130-7139.

Hégaret, H., Wikfors, G.H., Soudant, P., 2003. Flow cytometric analysis of haemocytes from eastern oysters, Crassostrea virginica, subjected to a sudden temperature elevation: II. Haemocyte functions: aggregation, viability, phagocytosis, and respiratory burst. J. Exp. Mar. Biol. Ecol. 293, 249-265. doi:10.1016/S0022-0981(03)00235-1

Hégaret, H., da Silva, P.M., Wikfors, G.H., Lambert, C., De Bettignies, T., Shumway, S.E., Soudant, P., 2007. Hemocyte responses of Manila clams, Ruditapesphilippinarum, with varying parasite, Perkinsusolseni, severity to toxic-algal exposures.Aquat. Toxicol. 84, 469479. doi:10.1016/j.aquatox.2007.07.007

Herzke, D., Anker-Nilssen, T., Nøst, T.H., Götsch, A., Christensen-Dalsgaard, S., Langset, M., Fangel, K., Koelmans, A.A., 2016. Negligible Impact of Ingested Microplastics on Tissue Concentrations of Persistent Organic Pollutants in Northern Fulmars off Coastal Norway. Environ. Sci. Technol. 50, 1924-1933.

Howard, D.W., Lewis, E.J., Keller, B.J., Smith, C.S., 2004. Histological techniques for marine bivalve mollusks and crustaceans.NOAA Technical Memorandum NOS NCCOS 5, 218.

Ivar do Sul, J.A., Costa, M.F., 2014. The present and future of microplastic pollution in the marine environment.Environ. Pollut. 185, 352-364. doi:10.1016/j.envpol.2013.10.036

Jo, P.G., Choi, Y.K., Choi, C.Y., 2008. Cloning and mRNA expression of antioxidant enzymes in the Pacific oyster, Crassostrea gigas in response to cadmium exposure. Comp. Biochem. Physiol. Part C Toxicol.Pharmacol. 147, 460-469. doi:10.1016/j.cbpc.2008.02.001

Kim, Y., Powell, E.N., Wade, T.L., Presley, B.J., 2008. Relationship of parasites and pathologies to contaminant body burden in sentinel bivalves: NOAA Status and Trends "Mussel Watch" Program. Mar. Environ. Res. 65, 101-127. doi:10.1016/j.marenvres.2007.09.003

Koelmans, A.A., Bakir, A., Burton, G.A., Janssen, C.R., 2016. Microplastic as a Vector for Chemicals in the Aquatic Environment: Critical Review and Model-Supported Reinterpretation of Empirical Studies. Environ. Sci. Technol. 50, 3315-3326.

Koelmans, A.A., Besseling, E., Foekema, E.M., 2014. Leaching of plastic additives to marine organisms.Environ. Pollut. 187, 49-54. doi:10.1016/j.envpol.2013.12.013

Lacroix, C., Coquillé, V., Guyomarch, J., Auffret, M., Moraga, D., 2014a. A selection of reference genes and early-warning mRNA biomarkers for environmental monitoring using Mytilus spp. as sentinel species.Mar. Pollut. Bull. 86, 304-313. doi:10.1016/j.marpolbul.2014.06.049 
Lacroix, C., Le Cuff, N., Receveur, J., Moraga, D., Auffret, M., Guyomarch, J., 2014b. Development of an innovative and "green" stir bar sorptive extraction-thermal desorptiongas chromatography-tandem mass spectrometry method for quantification of polycyclic aromatic hydrocarbons in marine biota. J. Chromatogr. A 1349, 1-10. doi:10.1016/j.chroma.2014.04.094

Lacroix, C., Richard, G., Seguineau, C., Guyomarch, J., Moraga, D., Auffret, M., 2015. Active and passive biomonitoring suggest metabolic adaptation in blue mussels (Mytilus spp.) chronically exposed to a moderate contamination in Brest harbor (France). Aquat. Toxicol. 162, 126-137. doi:10.1016/j.aquatox.2015.03.008

Lambert, C., Soudant, P., Dégremont, L., Delaporte, M., Moal, J., Boudry, P., Jean, F., Huvet, A., Samain, J.-F., 2007. Hemocyte characteristics in families of oysters, Crassostrea gigas, selected for differential survival during summer and reared in three sites. Aquaculture 270, 276-288. doi:10.1016/j.aquaculture.2007.03.016

Latendresse, J.R., Warbrittion, A.R., Jonassen, H., Creasy, D.M., 2002. Fixation of Testes and Eyes Using a Modified Davidson's Fluid: Comparison with Bouin's Fluid and Conventional Davidson's Fluid. Toxicol. Pathol. 30, 524-533. doi:10.1080/01926230290105721

Lotufo, G.R., 1998. Bioaccumulation of sediment-associated fluoranthene in benthic copepods: uptake, elimination and biotransformation. Aquat.Toxicol. 44, 1-15. doi:10.1016/S0166445X(98)00072-1

Lowry, O.H., N.J. Rosebrough, A.L. Farr, and R.J. Randall (1951) Protein Measurement with the Folin Phenol Reagent. J. Biol. Chem.193: 265-275.

Lyons, B.P., Thain, J.E., Stentiford, G.D., Hylland, K., Davies, I.M., Vethaak, A.D., 2010. Using biological effects tools to define Good Environmental Status under the European Union Marine Strategy Framework Directive. Mar. Pollut. Bull. 60, 1647-1651. doi:10.1016/j.marpolbul.2010.06.005

Mamaca, E., Bechmann, R.K., Torgrimsen, S., Aas, E., Bjørnstad, A., Baussant, T., Floch, S.L., 2005. The neutral red lysosomal retention assay and Comet assay on haemolymph cells from mussels (Mytilus edulis) and fish (Symphodusmelops) exposed to styrene. Aquat. Toxicol. 75, 191-201. doi:10.1016/j.aquatox.2005.08.001

Mato, Y., Isobe, T., Takada, H., Kanehiro, H., Ohtake, C., Kaminuma, T., 2001. Plastic Resin Pellets as a Transport Medium for Toxic Chemicals in the Marine Environment. Environ. Sci. Technol. 35, 318-324.

National Oceanic and Atmospheric Administration (NOAA), Proceedings of the International Research Workshop on the Occurrence, Effects, and Fate of Microplastic Marine Debris, C. Arthur, J. Baker, and H. Bamford (eds.), Technical Memorandum NOS-OR\&R-30, September 9-11, 2008, University of Washington Tacoma, Tacoma, WA, USA.

Oliveira, M., Ribeiro, A., Hylland, K., Guilhermino, L., 2013. Single and combined effects of microplastics and pyrene on juveniles ( $0+$ group) of the common goby Pomatoschistusmicrops (Teleostei, Gobiidae). Ecol. Indic. 34, 641-647. doi:10.1016/j.ecolind.2013.06.019

Ostroumov, S.A., 2003. Studying effects of some surfactants and detergents on filter-feeding bivalves.Hydrobiologia 500, 341-344. doi:10.1023/A:1024604904065

Palais, F., Dedourge-Geffard, O., Beaudon, A., Pain-Devin, S., Trapp, J., Geffard, O., Noury, P., Gourlay-Francé, C., Uher, E., Mouneyrac, C., Biagianti-Risbourg, S., Geffard, A., 2012. One-year monitoring of core biomarker and digestive enzyme responses in 
transplanted zebra mussels (Dreissenapolymorpha). Ecotoxicology 21, 888-905. doi:10.1007/s10646-012-0851-1

Pfaffl, M.W., 2001. A new mathematical model for relative quantification in real-time RT-PCR. Nucleic Acids Res. 29, e45.

Plastic Europe, 2015.Plastics - the Facts 2014/2015.An analysis of European plasticsproduction, demand and waste data. www.plasticseurope.fr

Ramos-Martinez, J.I., Bartolomé, T.R., Pernas, R.V., 1983. Purification and properties of glutathione reductase from hepatopancreas of Mytilus edulis L. Comp. Biochem.Physiol. Part B Comp. Biochem. 75, 689-692. doi:10.1016/0305-0491(83)90117-7

Regoli, F., Giuliani, M.E., Benedetti, M., Arukwe, A., 2011. Molecular and biochemical biomarkers in environmental monitoring: A comparison of biotransformation and antioxidant defense systems in multiple tissues. Aquat.Toxicol.,Jubileum 105, 56-66. doi:10.1016/j.aquatox.2011.06.014

Robert, R., Connan, J.P., Leroy, B., Chrétiennot-Dinet, M.J., Le Coz, J.R., Moal, J., Quéré, C., Martin-Jézéquel, V., Le Gourrierec, G., Nicolas, J.L., Bernard, E., Kaas, R., Le Déan, L. 2004. Amélioration des productions phytoplanctoniques en écloserie de mollusques : caractérisation des microalgues fourrage. Rapport Ifremer, 144p.

Rochman, C.M., Hoh, E., Kurobe, T., Teh, S.J., 2013. Ingested plastic transfers hazardous chemicals to fish and induces hepatic stress. Sci. Rep. 3.doi:10.1038/srep03263

Rodrigues, A.P., Lehtonen, K.K., Guilhermino, L., Guimarães, L., 2013. Exposure of Carcinusmaenas to waterborne fluoranthene: Accumulation and multibiomarker responses. Sci. Total Environ. 443, 454-463. doi:10.1016/j.scitotenv.2012.10.077

Roméo, M., Hoarau, P., Garello, G., Gnassia-Barelli, M., Girard, J.P., 2003. Mussel transplantation and biomarkers as useful tools for assessing water quality in the NW Mediterranean. Environ. Pollut. 122, 369-378. doi:10.1016/S0269-7491(02)00303-2

Romero, A., Dios, S., Poisa-Beiro, L., Costa, MM., Posada, D., Figueras, A., Novoa, B. 2011. Individual sequence variability and functional activities of fibrinogen-related proteins (FREPs) in the Mediterranean mussel (Mytilus galloprovincialis) suggest ancient and complex immune recognition models in invertebrates, Dev. Comp. Immunol. 35, 334-344. Doi: 10.1016/j.dci.2010.10.007.

Smital, T., Sauerborn, R., Hackenberger, B.K., 2003.Inducibility of the P-glycoprotein transport activity in the marine mussel Mytilusgalloprovincialis and the freshwater mussel Dreissenapolymorpha. Aquat.Toxicol. 65, 443-465. doi:10.1016/S0166-445X(03)00175-9

Sokal, R., Rohlf, F., 1981.Biometry.WH Freeman, New York.

Sussarellu, R., Soudant, P., Lambert, C., Fabioux, C ., Corporeau, C., Laot, C., Le Goic, N., Quillien, V., Boudry, P., Long, M., Mingant, C., Petton, B., Maes, T., Vethaak, D., Robbens, J., Huvet, A. 2016. Oyster reproduction is affected by exposure to polystyrene microplastics. P. Nat. Acad. Sci. 113, 2430-2435.

Van Cauwenberghe, L., Claessens, M., Vandegehuchte, M.B., Janssen, C.R., 2015. Microplastics are taken up by mussels (Mytilus edulis) and lugworms (Arenicola marina) living in natural habitats. Environ. Pollut. 199, 10-17. doi:10.1016/j.envpol.2015.01.008 
Velzeboer, I., Kwadijk, C.J.A.F., Koelmans, A.A., 2014. Strong Sorption of PCBs to Nanoplastics, Microplastics, Carbon Nanotubes, and Fullerenes. Environ. Sci. Technol. 48, 4869-4876.

Von Moos, N., Burkhardt-Holm, P., Köhler, A., 2012. Uptake and Effects of Microplastics on Cells and Tissue of the Blue Mussel Mytilus edulis L. after an Experimental Exposure. Environ. Sci. Technol. 46, 11327-11335. doi:10.1021/es302332w

Ward, J.E., Shumway, S.E., 2004. Separating the grain from the chaff: particle selection in suspension- and deposit-feeding bivalves. J. Exp. Mar. Biol. Ecol. 300, 83-130.

Wegner, A., Besseling, E., Foekema, E. m., Kamermans, P., Koelmans, A., 2012.Effects of nanopolystyrene on the feeding behavior of the blue mussel (Mytilus edulis L.). Environ. Toxicol.Chem. 31, 2490-2497. doi:10.1002/etc.1984

Wright, S.L., Thompson, R.C., Galloway, T.S., 2013. The physical impacts of microplastics on marine organisms: A review. Environ. Pollut. 178, 483-492. doi:10.1016/j.envpol.2013.02.031

Xiu, M., Pan, L., Jin, Q., 2014. Bioaccumulation and oxidative damage in juvenile scallop Chlamysfarreri exposed to benzo[a]pyrene, benzo[b]fluoranthene and chrysene. Ecotoxicol. Environ. Saf. 107, 103-110. doi:10.1016/j.ecoenv.2014.05.016

Zanette, J., Jenny, MJ., Goldstone, JV., Parente, T., Woodin, BR., Afonso CD., Bainy, ACD, Stegeman, JJ. 2013. Identification and expression of multiple CYP1-like and CYP3-like genes in the bivalve mollusk Mytilus edulis. Aqua. Toxicol.128-129, 101-112. Doi:10.1016/j.aquatox.2012.11.017. 
760 Figure 1.Concentrations ( $\mu \mathrm{g} \mathrm{g}^{-1}$, w.w.) of fluoranthene in gills and digestive gland of mussels 761 after exposure (T7) and depuration (T14) phases. Micro-PS: microplastics; FLU: fluoranthene.

762 Results are expressed as the mean concentration \pm standard error $(\mathrm{SE})(\mathrm{n}=9)$.

763 Figure 2. Histological observations in mussels after 7 days of exposure to fluoranthene and micro764 PS. A: Fluorescent $6 \mu \mathrm{m}$ and $2 \mu \mathrm{m}$ micro-PS in the intestine (INT) (arrows); B: Micro-PS (arrows) 765 in gills (G), Ep: epithelium; C: Ceroids (CER) in intestine (INT), Ep: epithelium; D: normal gills;

766 E: Vacuolization in gills (G VAC); F: Alteration in intestine epithelium (AEp), normal intestine 767 epithelium (Nep); G: Hemocyte infiltration (HI) in conjunctive tissue of digestive gland (full arrows). Hemocyte in diapedesis in intestine epithelium (empty arrows); H: Normal digestive tubules (DT); I: Hemocytes infiltration in conjunctive tissues of digestive gland.

770 Figure 3.Sum ofhistopathological observations detected in mussel tissues (gills, gonads and 771 digestive gland including stomach, digestive tubules and intestine) after exposure (T7) and 772 depuration (T14).TA: tissue alterations (degeneration, sloughing, tear); INF: Hemocyte 773 infiltration; DIA: Hemocyte in diapedesis (observed only in digestive gland including stomach, 774 digestive tubules and intestine); CER: Ceroids; VAC: Vacuolation. Letters ( $\mathrm{a}, \mathrm{b}, \mathrm{c})$ indicate 775 statistical differences (Mann-Whitney U-test, $\mathrm{p}<0.05$ ).

776 Figure 4. Percentage of dead hemocytes (\%) (A), ROS production capacity (B) andphagocytosis 777 capacity (C) after exposure (T7) and depuration (T14) phases. Micro-PS: microplastics; FLU: 778 fluoranthene. Results are expressed as mean percentage of mortality \pm standard error (SE) $(n=12)$.

779 Figure 5.Anti-oxidant enzyme activities (CAT, SOD, GST,GR) and lipid peroxidation (LPO) 780 measured in digestive gland of mussels after exposure (T7) and depuration (T14). Results are expressed as mean percentage of mortality \pm standard error $(\mathrm{SE})(\mathrm{n}=9)$. 


\section{$785 \quad$ Figure 1}

786
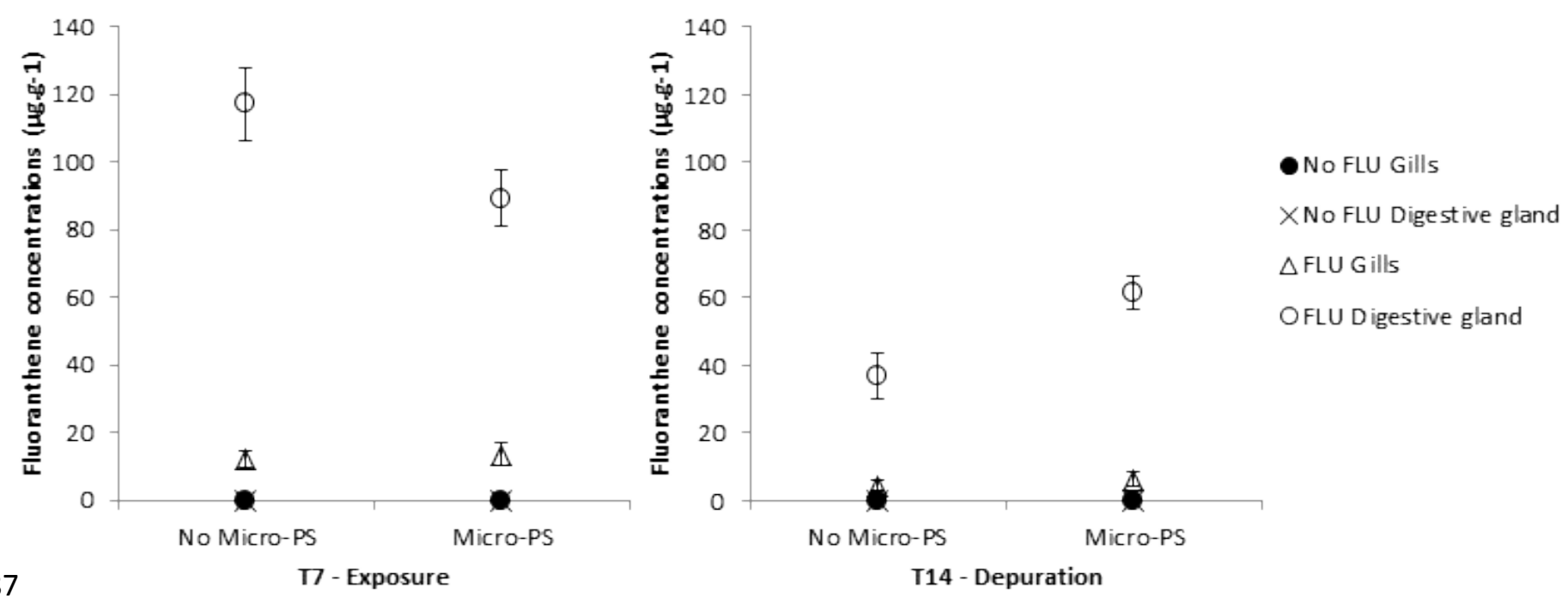

788 
Figure 2
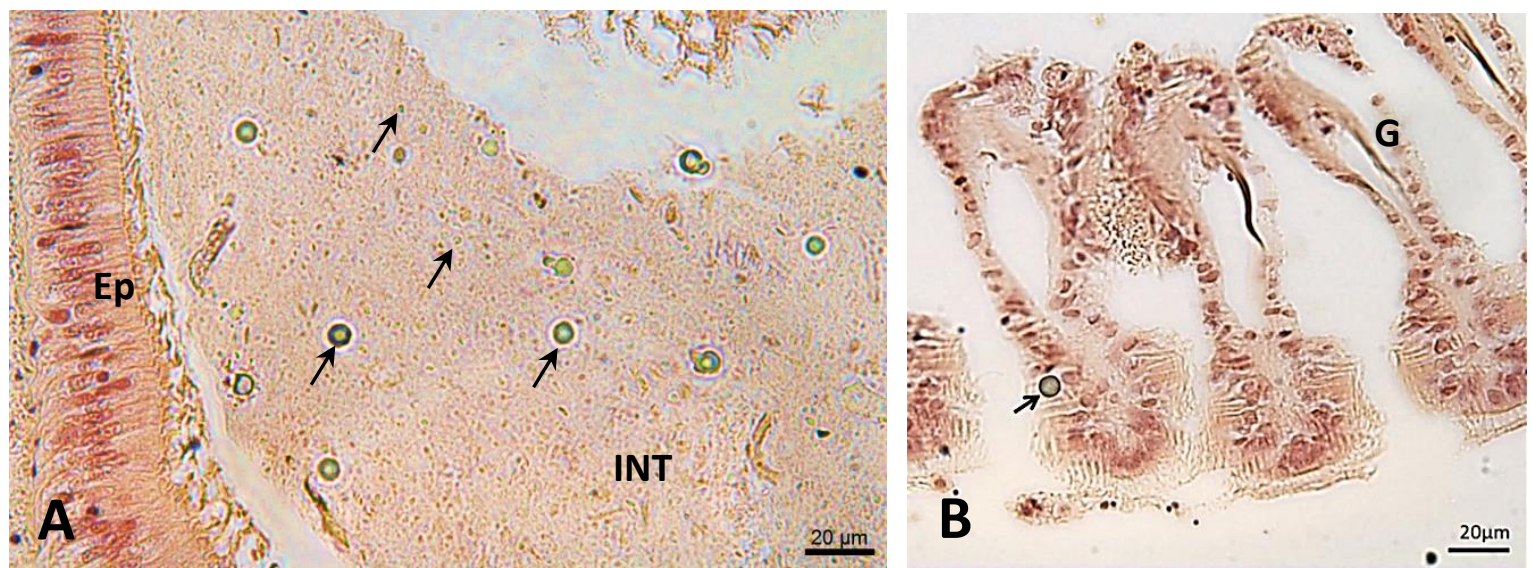

B
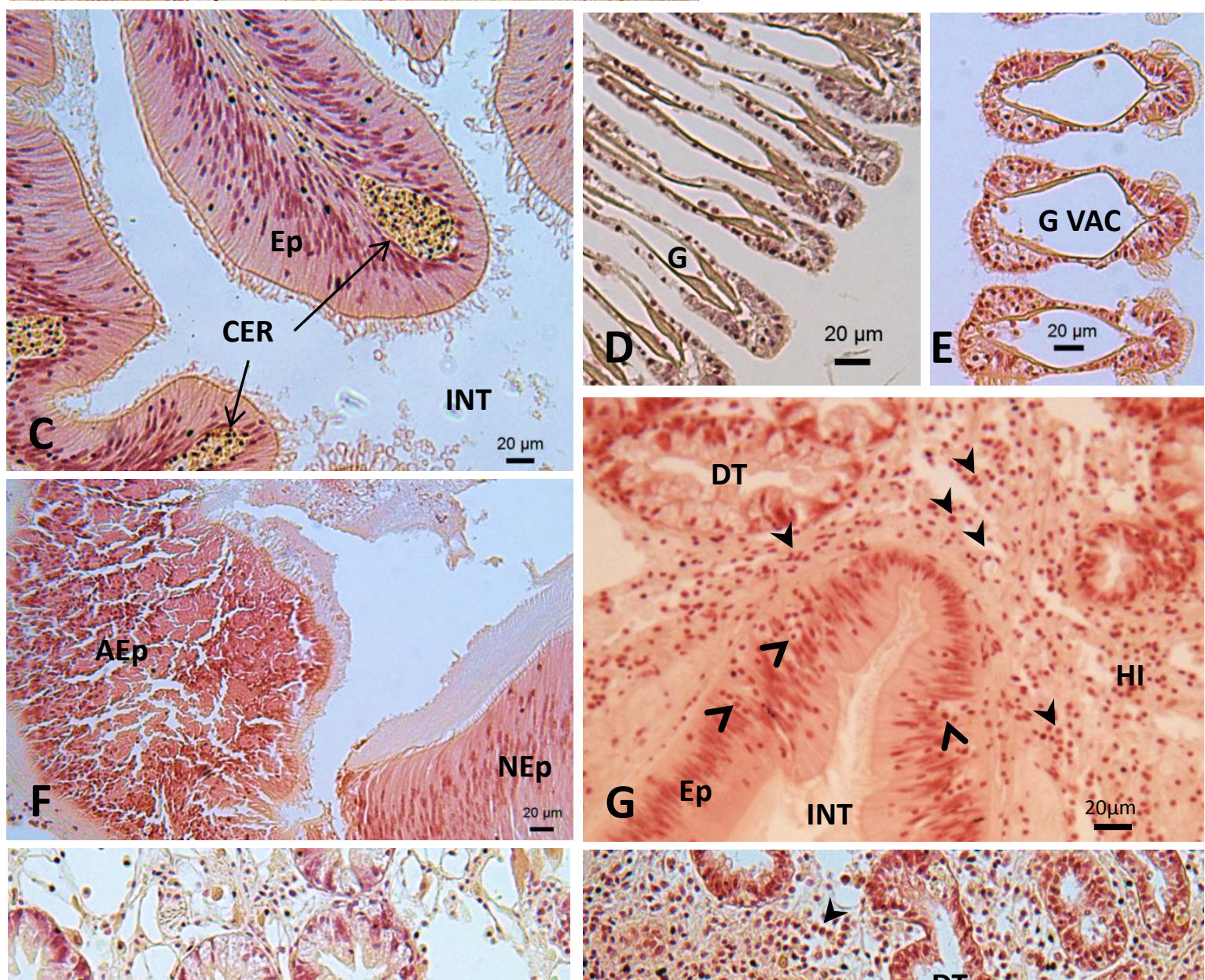

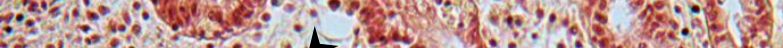

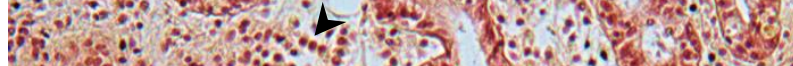
2. 10 or 3

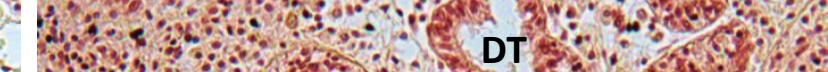

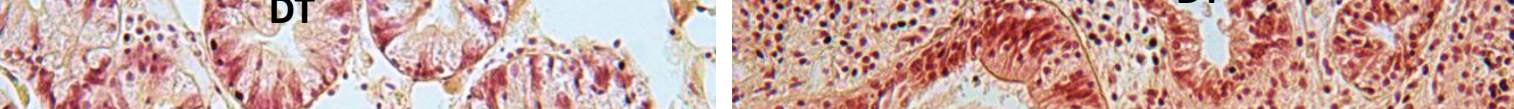

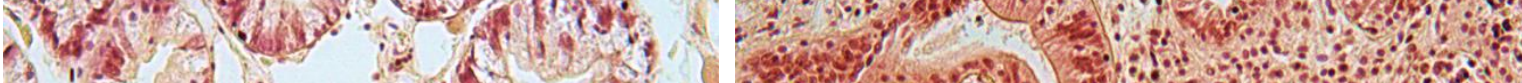

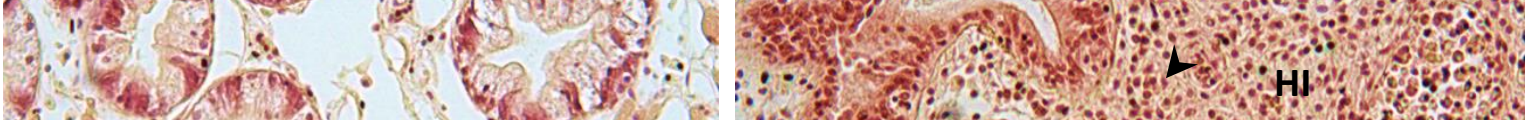

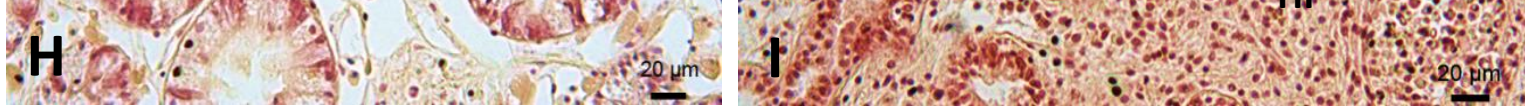


Figure 3

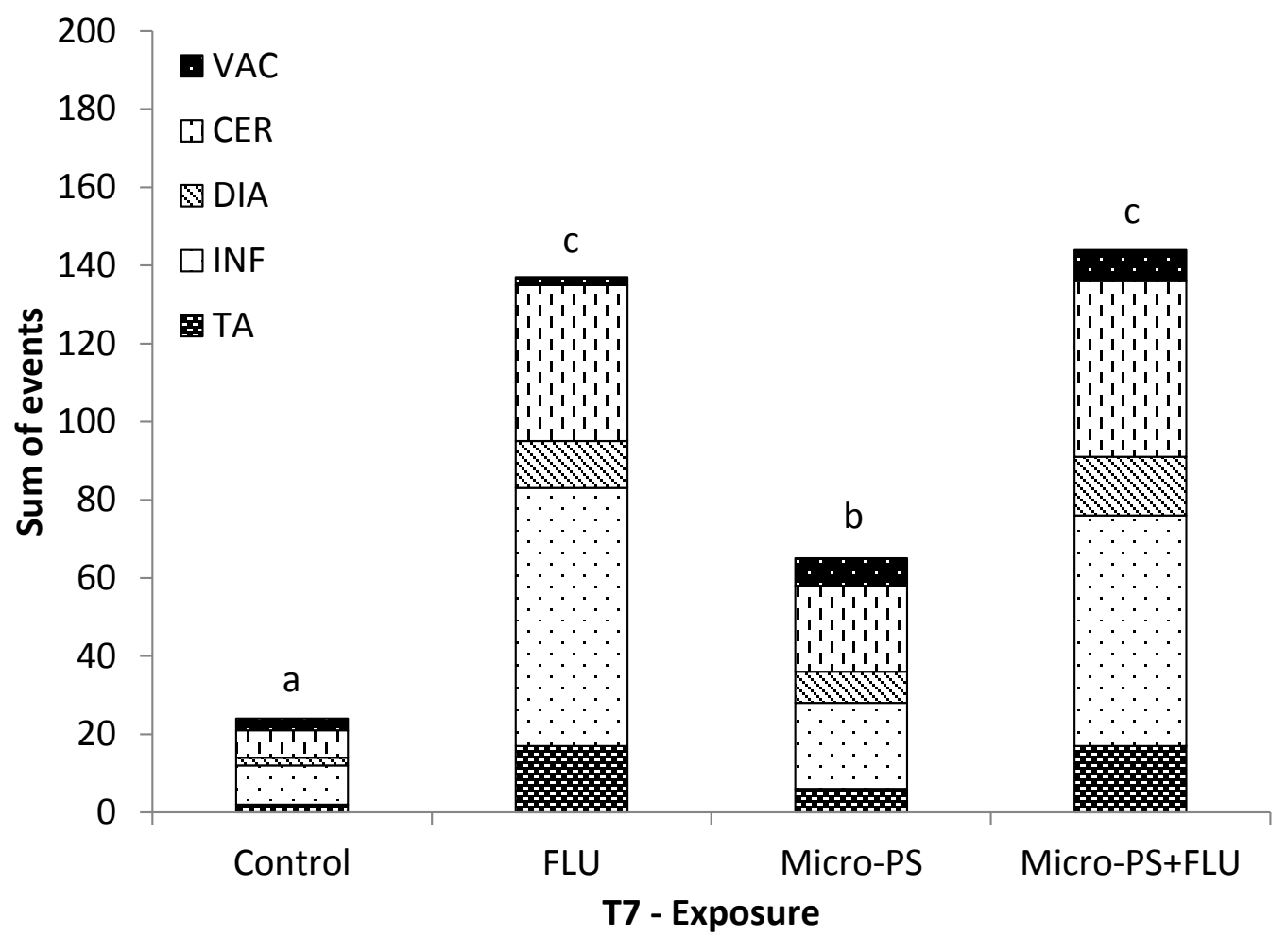

794

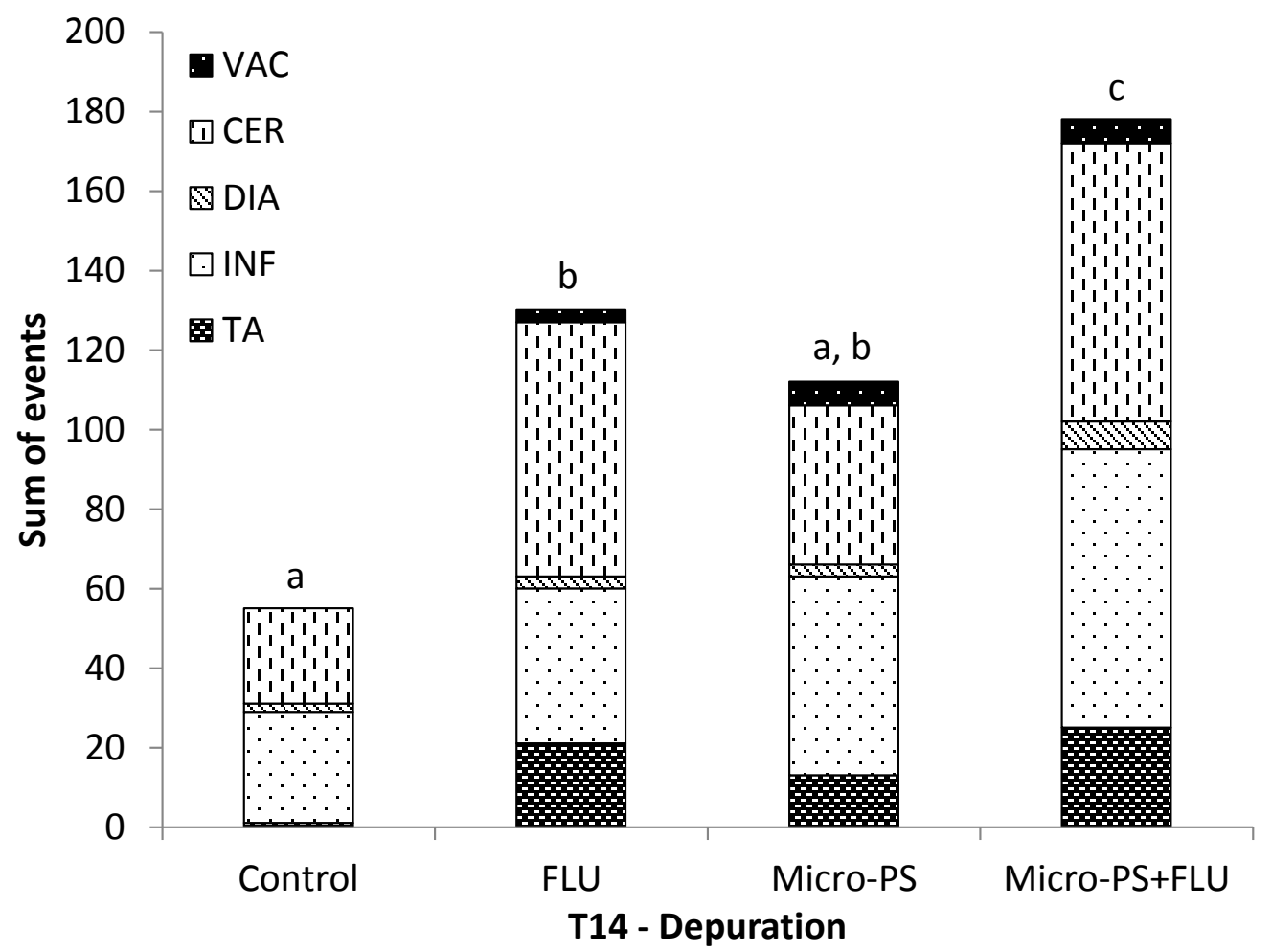

795 
$800 \quad$ Figure 4

A
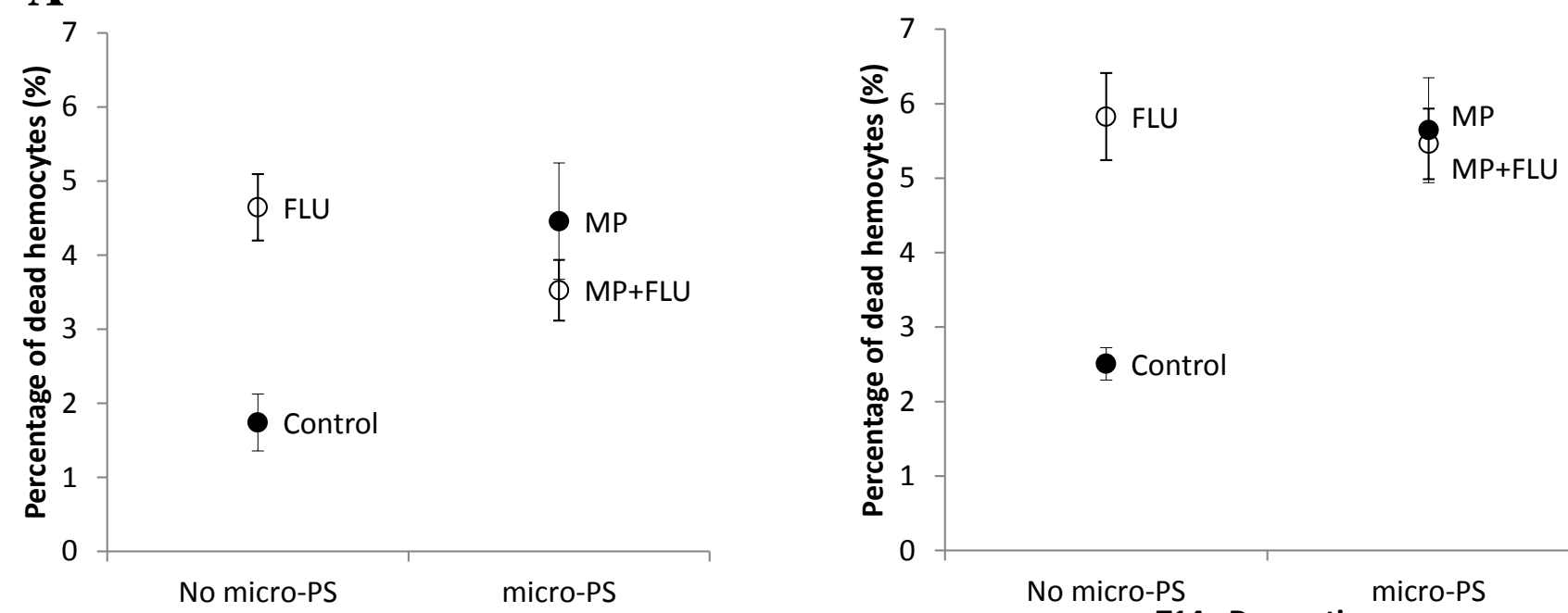

$801 \quad$ T7 - Exposure

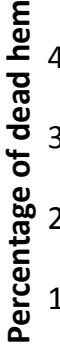

1

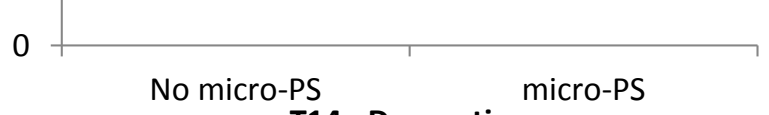

T14 - Depuration

B
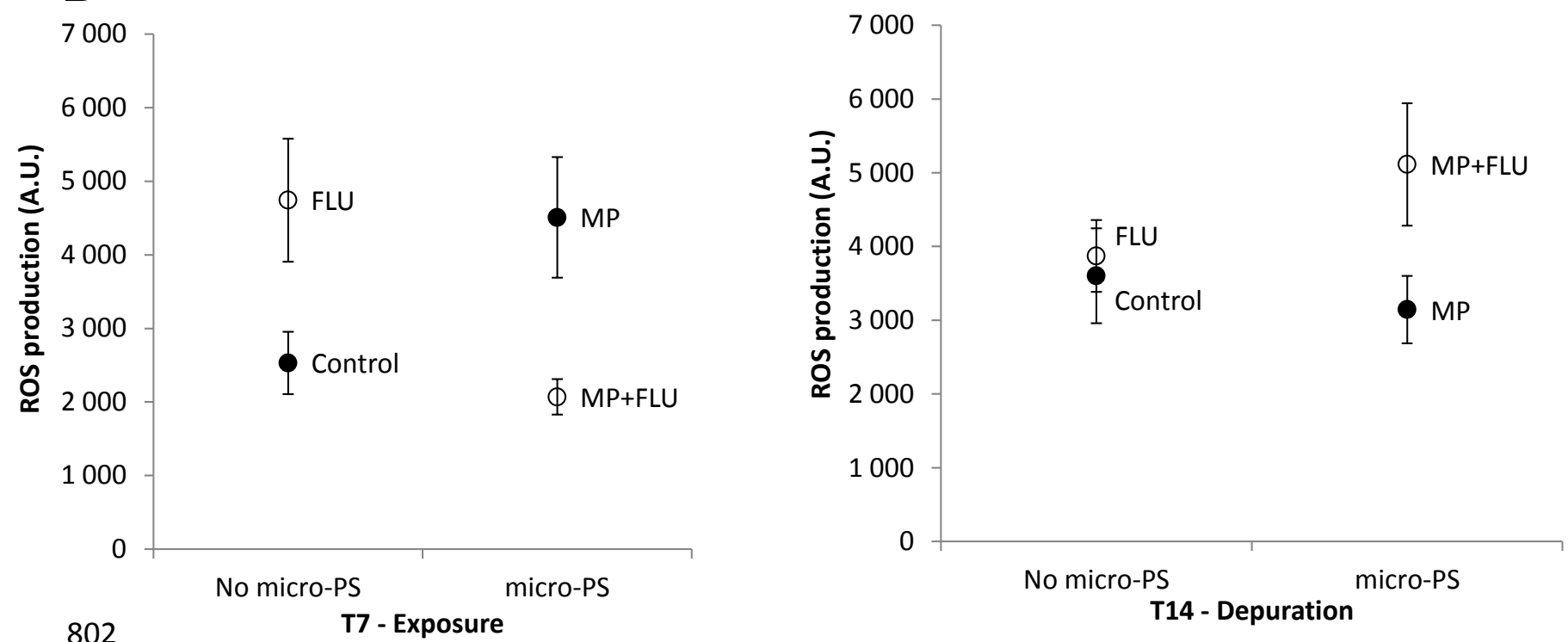

C

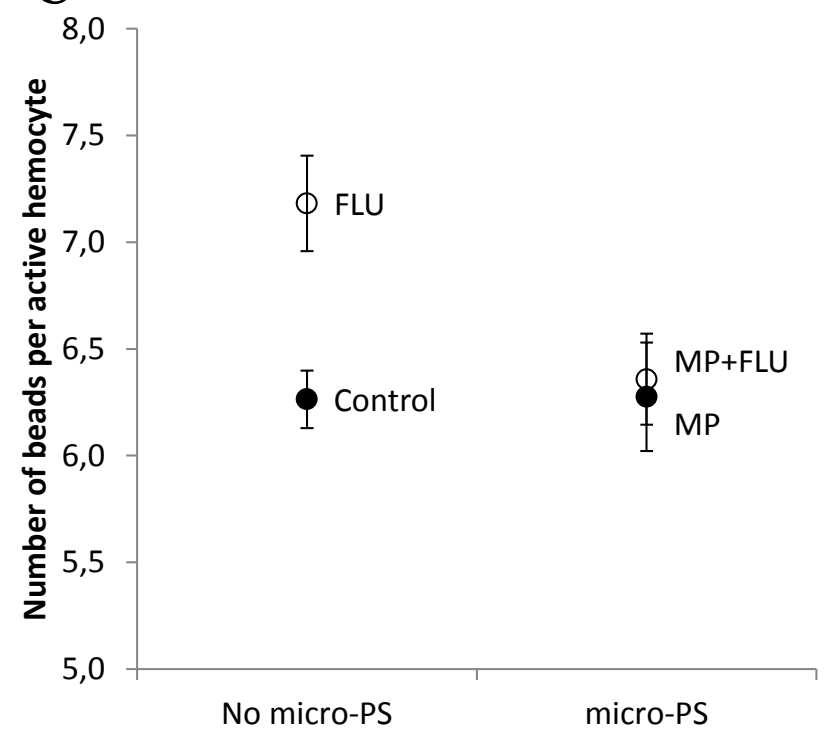

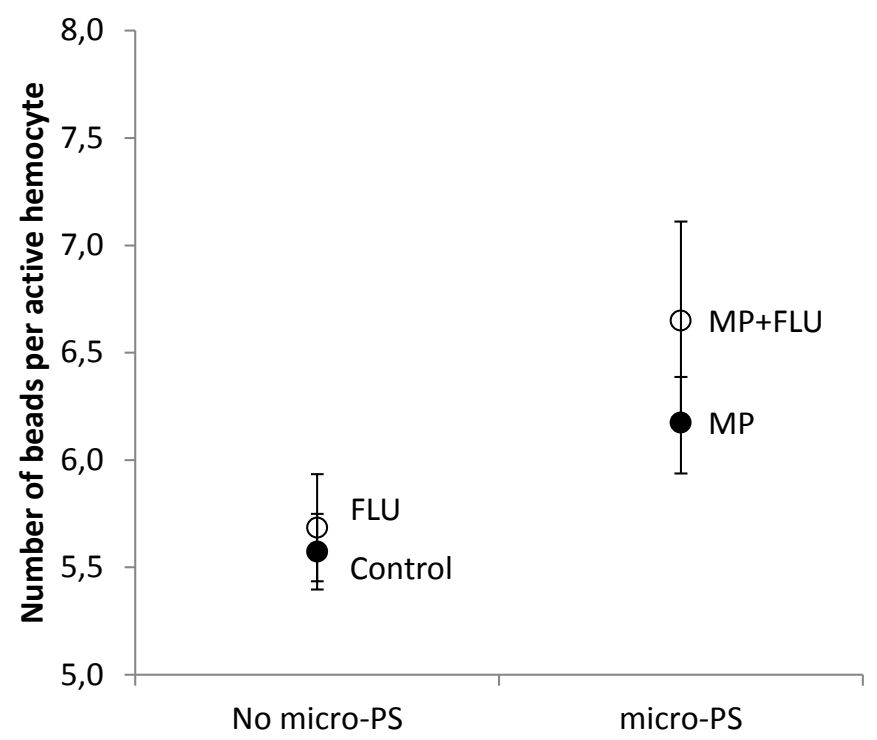

T14 - Depuration 


\section{Figure 5}

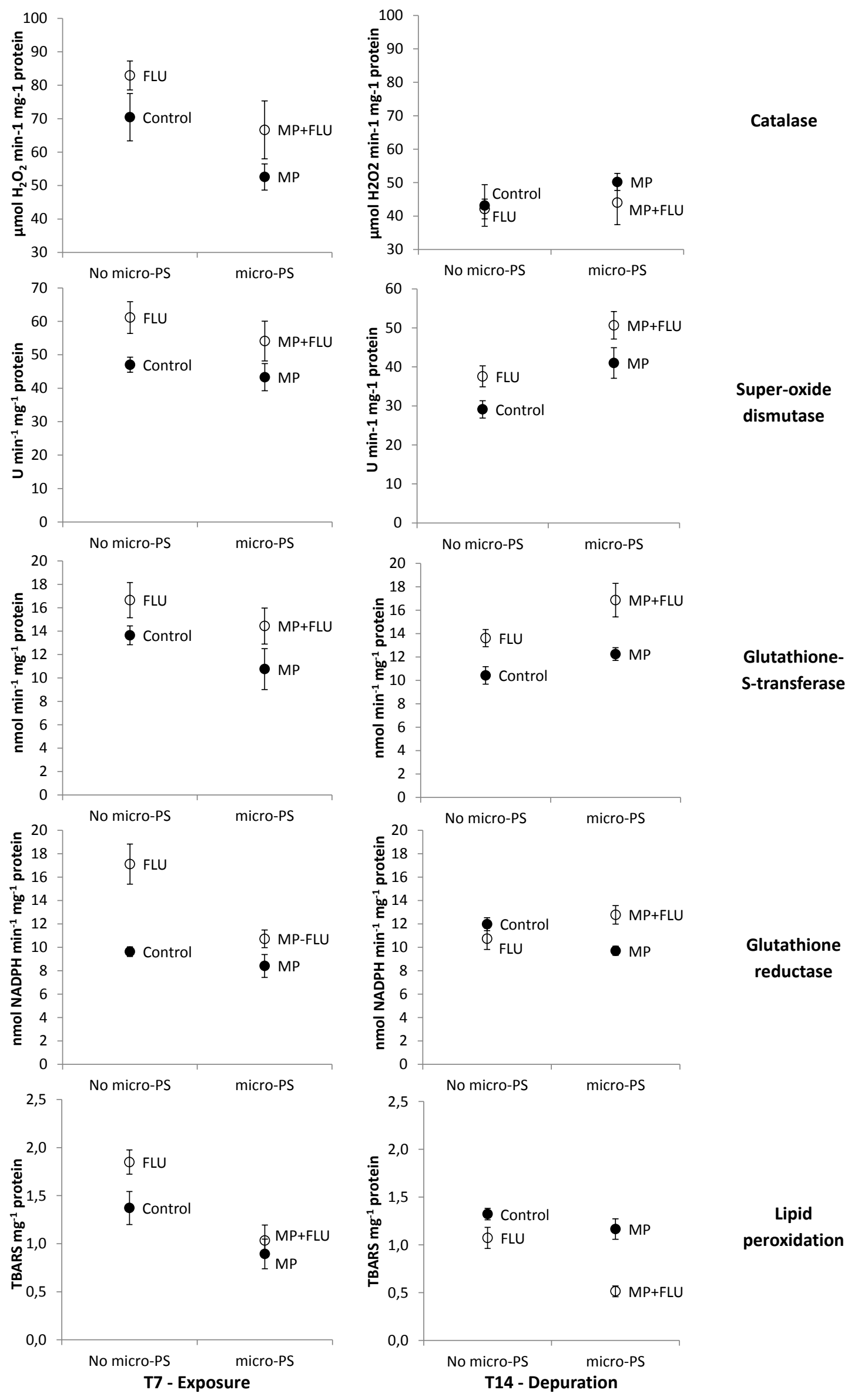


Tables

Table 1. Name, abbreviation, primer pair, efficiency, linear range, product length, melting temperature (Tm), and Genbank accession numbers for reference and target genes analyzed in mussel tissues exposed to micro-PS and FLU. G: gills, DG: digestive glands, bp: base pair.

\begin{tabular}{|c|c|c|c|c|c|c|c|c|}
\hline Transcript name & Abreviation & Forward $\left(5^{\prime}-3^{\prime}\right)$ & Reverse (5'-3') & $\begin{array}{c}\text { Efficiency } \\
\text { (G/DG) }\end{array}$ & $\begin{array}{l}\text { Length } \\
\text { (bp) }\end{array}$ & $\begin{array}{l}\mathrm{Tm} \\
\left({ }^{\circ} \mathrm{C}\right)\end{array}$ & Accession number (species) & Reference \\
\hline $28 \mathrm{~S}$ rRNA * & $28 s$ & GGAGGTCCGTAGCGATTCTG & CGTCCCCAAGGCCTCTAATC & $1.96 / 1.94$ & 174 & 81.8 & AB103129 (mg) & Lacroix et al, 2014a \\
\hline Elongation factor 1 alpha * & ef $1 \alpha$ & ACCCAAGGGAGCCAAAAGTT & TGTCAACGATACCAGCATCC & $1.92 / 1.95$ & 212 & 79.2 & AF063420 (me) / ABA62021 (mg) & Lacroix et al, 2014a \\
\hline Elongation factor $2 *$ & ef2 & GCAGTACATCACCCAGCAAA & GTCAACAAGGCCAAGTCCAT & $1.89 / 1.88$ & 249 & 80.1 & $\mathrm{FL} 497408$ (mg) & Lacroix et al, 2014a \\
\hline Ribosomal protein $\mathrm{L7}$ * & $r p l 7$ & CAGAGACAGGCCAAGAAAGG & TGGGTAGCCCCATGTAATGT & $1.95 / 1.95$ & 227 & 81.9 & AJ516457 (mg) & Lacroix et al, 2014a \\
\hline alpha-tubuline * & $\alpha t u b$ & GGATTCAAGGTCGGAATCAA & ACGTACCAATGGACGAAAGC & $1.92 / 1.97$ & 179 & 83.6 & DQ174100 (me) / HM537081 (mg) & Lacroix et al, 2014a \\
\hline Catalase & cat & CACCAGGTGTCCTTCCTGTT & CTTCCGAGATGGCGTTGTAT & $1.86 / 1.85$ & 235 & 81.5 & AY580271 (me) / AY743716 (mg) & Lacroix et al, 2014a \\
\hline $\mathrm{Cu} / \mathrm{Zn}$-Superoxide Dismutase & sod & CATTTCCCAGATCACCAACA & GGAACAGTCGCTTTCAGTCA & $1.93 / 1.90$ & 214 & 82.2 & AJ581746 (me) / FM177867 (mg) & Lacroix et al, 2014a \\
\hline Se-dependant-Glutathione peroxidase & $g p x$ & ACGGTAAAGACGCTCATCCAA & TCTTGTCACAGGTTCCCATATGAT & $2.00 / 2.06$ & 119 & 79.7 & HQ891311 (mg) & Lacroix et al, 2014a \\
\hline Cytochrome P450-1-like-1 & сур11 & TGGTTGCGATTTGTTATGCCCTGGA & GGCGGAAAGCAATCCATCCGTGA & ND/1.95 & 150 & 77.5 & JX885878 (me) & Zanette et al., 2013 \\
\hline Cytochrome P450-3-like-2 & сур32 & CAGACGCGCCAAAAGTGATA & GTCCCAAGCCAAAAGGAAGG & $1.87 / 1.85$ & 194 & 80.1 & AB479539 (me) & Lacroix et al, 2014a \\
\hline$\omega$-Glutathione-S-transferase & $\omega g s t$ & CGACTCTATAGCATGCGATTATG & AGAACCGGAACCATACCAAGAGG & $1.92 / 2.04$ & 152 & 77.5 & Locus $38757^{\mathrm{a}}$ (me) & Lacroix et al, 2014a \\
\hline$\mu$-Glutathione-S-transferase & $\mu g s t$ & AGAGGCCTAGCACAGCCAGTGAG & САСTCTCTGCTGAATCCTGGACC & $2.05 / 1.95$ & 104 & 78.4 & Locus $42054^{\mathrm{a}}$ (me) & Lacroix et al, 2014a \\
\hline$\sigma$-Glutathione-S-transferase & $\sigma g s t$ & CCTGTTCGCGGAAGAGCTGAACT & GTTGGCATCTGTCCTGTTGGTAT & 1.92/NA & 131 & 78.0 & $\mathrm{FL} 494070$ (mg) & Lacroix et al, 2014a \\
\hline Growth arrest and DNA damage inducible & gadd $45 \alpha$ & ССАТТСССТТСААССТССТС & GCCGAAACAGACGTAACAGT & $1.96 / 1.89$ & 140 & 78.7 & AJ623737 (mg) & Ruiz et al, 2012 \\
\hline$\alpha$-Amylase & amylase & CCTCGGGGTAGCTGGTITIA & TCCAAAGTTACGGGCTCCTT & ND/1.91 & 232 & 79.2 & EU336958 (me) & - \\
\hline Pyruvate kinase & $p k$ & AGACTTGGAGCTGCCTTCAG & GGAATGCACAGAGGGTTCAT & $1.83 / 1.88$ & 228 & 81.6 & Locus $22823^{\mathrm{a}}$ (me) & - \\
\hline ocitrate dehydrogenase [NADP] cytoplasm & $i d p$ & GGAGGTACTGTATTTCGTGAGGC & TGATCTCCATAAGCATGACGTCC & $1.93 / 1.97$ & 104 & 76.9 & Locus $2855^{\mathrm{a}}$ (me) & - \\
\hline jyceraldehyde 3 phosphate dehydrogenas & gapdh & GTCTGGTGATGAGAGCTGCC & GCGTCTCCCCATTTGATAGCT & $1.84 / 1.84$ & 220 & 78.7 & $\mathrm{FL} 496349(\mathrm{mg})$ & Lacroix et al, 2014a \\
\hline Hexokinase & $h k$ & CCAATATGACAATTGCCGTTGA & GCAGCACCTTTACCACTACCATCA & $1.91 / 1.91$ & 148 & 78.2 & JN595865 (mg) & - \\
\hline P-53 tumor supressor-like & $p 53$ & CAACAACTTGCCCAATCCGA & GGCGGCTGGTATATGGATCT & $1.85 / 1.89$ & 228 & 80.1 & AY579472 (me) / DQ158079 (mg) & Lacroix et al, 2014a \\
\hline ABCB/P-glycoprotein-like protein & pgp & CACTAGTTGGAGAGCGTGGA & TGTTCTTCCCTGTCTTGCCT & $1.92 / 1.86$ & 116 & 82.7 & AF159717 (me) / EF057747 (mg) & Lacroix et al, 2014a \\
\hline Lysosyme & lys & AGGGTTTGTGCATCCTCTTG & TCGACTGTGGACAACCAAAA & $1.94 / 1.92$ & 173 & 81.6 & AF334662 (me) / AF334665 (mg) & - \\
\hline Caspase $3 / 7-3$ & casp $37-3$ & CAATGTGTAAAAACGAGAGACATTG & GTAATATATGCCCACTGTCCATTC & $1.84 / 1.93$ & 146 & 76.5 & HQ424453 (mg) & Romero et al., 2011 \\
\hline
\end{tabular}

* indicates reference genes; ${ }^{\mathbf{a}}$ indicates sequences obtained from Illumina technology sequencing (Courtesy of Sleiman Bassim and Arnaud Tanguy (Bassim et al,

2014)); (me): M. edulis; (mg): M. galloprovincialis. ND: not detected; NA: not analyzed 
Table 2. Concentrations of fluoranthene in water, on micro-algae Chaetoceros muelleri and on polystyrene microbeads (micro-PS) expressed as $\mathrm{ng} \mathrm{mL} \mathrm{m}^{-1}$, percentage $(\%)$ or partition coefficient $(\log \mathrm{Kp})$ in the FLU and micro-PS+FLU algal cultures.

\begin{tabular}{ccccccc}
\hline & \multicolumn{3}{c}{ FLU alone } & \multicolumn{3}{c}{ Micro-PS+FLU } \\
\hline & $\left(\mathrm{ng} \mathrm{m}^{-1}\right)$ & $\%$ & Log Kp & ${\left.\text { (ng } \mathbf{~ L}^{-1}\right)}^{\text {) }}$ & Log Kp \\
\hline Micro-algae & 325.59 & 89 & 4.84 & 234.66 & 67 & 4.77 \\
Water & 39.30 & 11 & $/$ & 40.19 & 12 & $/$ \\
$\mathbf{2} \boldsymbol{\mu m}$ micro-PS & $/$ & $/$ & $/$ & 18.35 & 5 & 6.58 \\
$\mathbf{6} \boldsymbol{\mu m}$ micro-PS & $/$ & $/$ & $/$ & 55.05 & 16 & 6.59 \\
\hline
\end{tabular}


Table 3. Results of the two-way ANOVA performed on the hemocyte parameters measured in mussels exposed to microplastics (micro-PS) and fluoranthene (FLU) alone or in combination after exposure (T7) and depuration (T14). Only parameters exhibiting levels significantly modulated by micro-PS and/or FLU are presented here. P-values $<0.05$ are in bold and italic character.

\begin{tabular}{|c|c|c|c|c|c|c|c|c|c|c|}
\hline \multirow[b]{2}{*}{$\begin{array}{l}\text { Source of } \\
\text { variation }\end{array}$} & \multicolumn{2}{|c|}{$\begin{array}{c}\text { Hemocyte } \\
\text { mortality }\end{array}$} & \multicolumn{2}{|c|}{$\begin{array}{c}\text { ROS } \\
\text { production }\end{array}$} & \multicolumn{2}{|c|}{$\begin{array}{c}\text { Phagocytosis } \\
\text { capacity }\end{array}$} & \multicolumn{2}{|c|}{$\begin{array}{c}\text { Hemocyte } \\
\text { concentration }\end{array}$} & \multicolumn{2}{|c|}{$\begin{array}{c}\text { Granulocyte } \\
\text { concentration }\end{array}$} \\
\hline & $\begin{array}{c}\text { T7 } \\
\text { p-value }\end{array}$ & $\begin{array}{c}\text { T14 } \\
\text { p-value }\end{array}$ & $\begin{array}{c}\text { T7 } \\
\text { p-value }\end{array}$ & $\begin{array}{c}\text { T14 } \\
\text { p-value }\end{array}$ & $\begin{array}{c}\text { T7 } \\
\text { p-value }\end{array}$ & $\begin{array}{c}\text { T14 } \\
\text { p-value }\end{array}$ & $\begin{array}{c}\text { T7 } \\
\text { p-value }\end{array}$ & $\begin{array}{c}\text { T14 } \\
\text { p-value }\end{array}$ & $\begin{array}{c}\text { T7 } \\
\text { p-value }\end{array}$ & $\begin{array}{c}\text { T14 } \\
\text { p-value }\end{array}$ \\
\hline FLU & 0.013 & 0.001 & 0.048 & $>0.05$ & $>0.05$ & $>0.05$ & $>0.05$ & $>0.05$ & $>0.05$ & $>0.05$ \\
\hline Micro-PS & 0.049 & 0.003 & 0.041 & $>0.05$ & $>0.05$ & 0.01 & $>0.05$ & 0.001 & $>0.05$ & $<0.0001$ \\
\hline Micro-PSxFLU & 0.001 & $<0.0001$ & 0.001 & $>0.05$ & 0.018 & $>0.05$ & $>0.05$ & $>0.05$ & $>0.05$ & $>0.05$ \\
\hline
\end{tabular}

Table 4. Results of the two-way ANOVA performed on the enzyme activities measured in mussels exposed to microplastics (micro-PS) and fluoranthene (FLU) alone or in combination after exposure (T7) and depuration (T14). Only parameters exhibiting levels significantly modulated by micro-PS and/or FLU are presented here. P-values $<0.05$ are in bold and italic character.

\begin{tabular}{|c|c|c|c|c|c|c|c|c|c|c|}
\hline \multirow[b]{2}{*}{$\begin{array}{l}\text { Source of } \\
\text { variation }\end{array}$} & \multicolumn{2}{|c|}{ Catalase } & \multicolumn{2}{|c|}{$\begin{array}{l}\text { Superoxide } \\
\text { dismutase }\end{array}$} & \multicolumn{2}{|c|}{$\begin{array}{l}\text { Glutathione-S- } \\
\text { transferase }\end{array}$} & \multicolumn{2}{|c|}{$\begin{array}{c}\text { Glutathione } \\
\text { reductase }\end{array}$} & \multicolumn{2}{|c|}{ Lipid peroxidation } \\
\hline & $\begin{array}{c}\text { T7 } \\
\text { p-value }\end{array}$ & $\begin{array}{c}\text { T14 } \\
\text { p-value }\end{array}$ & $\begin{array}{c}\text { T7 } \\
\text { p-value }\end{array}$ & $\begin{array}{c}\text { T14 } \\
\text { p-value }\end{array}$ & $\begin{array}{c}\text { T7 } \\
\text { p-value }\end{array}$ & $\begin{array}{c}\text { T14 } \\
\text { p-value }\end{array}$ & $\begin{array}{c}\text { T7 } \\
\text { p-value }\end{array}$ & $\begin{array}{c}\text { T14 } \\
\text { p-value }\end{array}$ & $\begin{array}{c}\text { T7 } \\
\text { p-value }\end{array}$ & $\begin{array}{c}\text { T14 } \\
\text { p-value }\end{array}$ \\
\hline FLU & $>0.05$ & $>0.05$ & 0.021 & 0.016 & $>0.05$ & 0.001 & $<0.0001$ & $>0.05$ & $>0.05$ & $<0.0001$ \\
\hline Micro-PS & 0.025 & $>0.05$ & $>0.05$ & 0.004 & $>0.05$ & 0.041 & 0.003 & $>0.05$ & 0.001 & 0.003 \\
\hline Micro-PSxFLU & $>0.05$ & $>0.05$ & $>0.05$ & $>0.05$ & $>0.05$ & $>0.05$ & $>0.05$ & 0.021 & $>0.05$ & 0.021 \\
\hline
\end{tabular}


Table 5. Relative gene expression in gills (G) and digestive glands (DG) of mussels exposed to microplastics (micro-PS) and fluoranthene (FLU) alone or in combination after exposure (T7) and depuration (T14). Only anti-oxidant genes exhibiting mRNA levels significantly modulated by micro-PS and/or FLU are presented here, alongside with the results of the two-way ANOVA (pvalue). P-values $<0.05$ are in bold and italic character highlighted in grey. Arrows represent the way of induction, $\nearrow$ : up-regulation; $\searrow$ : down-regulation; $\uparrow$ : interaction.

\begin{tabular}{|c|c|c|c|c|c|c|c|c|c|}
\hline \multirow{2}{*}{ Function } & \multirow{2}{*}{ Gene } & \multirow{2}{*}{ Time } & \multirow{2}{*}{ Tissue } & \multirow{2}{*}{$\begin{array}{c}\text { Experimental } \\
\text { conditions }\end{array}$} & \multicolumn{3}{|c|}{ Relative gene expression } & \multirow{2}{*}{\multicolumn{2}{|c|}{ p-value }} \\
\hline & & & & & Mean & SD & SE & & \\
\hline & cat & $\mathrm{T7}$ & G & Control & 1,35 & 0,33 & 0,11 & & \\
\hline & & & & FLU & 1,37 & 0,36 & 0,12 & $>0.05$ & \\
\hline & & & & Micro-PS & 0,97 & 0,26 & 0,09 & 0,006 & y \\
\hline & & & & Micro-PS x FLU & 1,13 & 0,31 & 0,10 & $>0.05$ & \\
\hline & cat & T14 & G & Control & 0,97 & 0,29 & 0,10 & & \\
\hline & & & & FLU & 0,70 & 0,23 & 0,08 & $>0.05$ & \\
\hline & & & & Micro-PS & 0,92 & 0,27 & 0,09 & 0,029 & $\searrow$ \\
\hline & & & & Micro-PS x FLU & 1,14 & 0,19 & 0,06 & 0,006 & $\uparrow$ \\
\hline & sod & T14 & G & Control & 0,97 & 0,29 & 0,10 & & \\
\hline & & & & FLU & 0,70 & 0,23 & 0,08 & 0,002 & オ \\
\hline & & & & Micro-PS & 0,92 & 0,27 & 0,09 & 0,036 & $\lambda$ \\
\hline & & & & Micro-PS x FLU & 1,14 & 0,19 & 0,06 & $>0.05$ & \\
\hline \multirow{16}{*}{ Anti-oxidant } & $g p x$ & T14 & G & Control & 0,81 & 0,68 & 0,23 & & \\
\hline & & & & FLU & 1,87 & 1,76 & 0,62 & 0,042 & $\lambda$ \\
\hline & & & & Micro-PS & 1,48 & 0,38 & 0,13 & $>0.05$ & \\
\hline & & & & Micro-PS x FLU & 2,22 & 1,49 & 0,50 & $>0.05$ & \\
\hline & $\sigma-g s t$ & T14 & DG & Control & 1,55 & 0,97 & 0,32 & & \\
\hline & & & & FLU & 1,05 & 0,70 & 0,23 & 0,014 & $\searrow$ \\
\hline & & & & Micro-PS & 1,84 & 0,96 & 0,36 & $>0.05$ & \\
\hline & & & & Micro-PS x FLU & 0,87 & 0,42 & 0,15 & $>0.05$ & \\
\hline & cat & T14 & DG & Control & 1,26 & 0,96 & 0,32 & & \\
\hline & & & & FLU & 0,90 & 0,38 & 0,13 & $>0.05$ & \\
\hline & & & & Micro-PS & 0,87 & 0,37 & 0,14 & $>0.05$ & \\
\hline & & & & Micro-PS x FLU & 2,09 & 1,29 & 0,46 & 0,016 & $\uparrow$ \\
\hline & sod & T14 & DG & Control & 0,68 & 0,24 & 0,08 & & \\
\hline & & & & FLU & 1,05 & 0,15 & 0,05 & $<0,0001$ & $\lambda$ \\
\hline & & & & Micro-PS & 0,77 & 0,28 & 0,11 & $>0.05$ & \\
\hline & & & & Micro-PS x FLU & 1,12 & 0,17 & 0,06 & $>0.05$ & \\
\hline
\end{tabular}


Table 6. Relative gene expression in gills (G) and digestive glands (DG) of mussels exposed to microplastics (micro-PS) and fluoranthene (FLU) alone or in combination after exposure (T7) and depuration (T14). Only genes exhibiting mRNA levels significantly modulated by micro-PS and/or FLU are presented here, alongside with the results of the two-way ANOVA (p-value). Pvalues $<0.05$ are in bold character highlighted in grey. Arrows represent the way of induction, $\nearrow$ : up-regulation; $\searrow$ : down-regulation; $\uparrow$ : interaction.

\begin{tabular}{|c|c|c|c|c|c|c|c|c|c|}
\hline \multirow{2}{*}{ Function } & \multirow{2}{*}{ Gene } & \multirow{2}{*}{ Time } & \multirow{2}{*}{ Tissue } & \multirow{2}{*}{$\begin{array}{c}\text { Experimental } \\
\text { conditions }\end{array}$} & \multicolumn{3}{|c|}{ Relative gene expression } & \multirow{2}{*}{\multicolumn{2}{|c|}{ p-value }} \\
\hline & & & & & Mean & SD & SE & & \\
\hline & $i d p$ & T14 & G & Control & 0,20 & 0,08 & 0,03 & & \\
\hline Generation & & & & FLU & 0,48 & 0,20 & 0,07 & 0,008 & $\lambda$ \\
\hline of reducing & & & & Micro-PS & 0,39 & 0,29 & 0,10 & $>0.05$ & \\
\hline equivalents & & & & Micro-PS x FLU & 0,51 & 0,21 & 0,07 & $>0.05$ & \\
\hline \multirow{4}{*}{ Detoxication } & pgp & T14 & DG & Control & 1,45 & 0,51 & 0,17 & & \\
\hline & & & & FLU & 1,12 & 0,29 & 0,10 & $>0.05$ & \\
\hline & & & & Micro-PS & 0,62 & 0,28 & 0,11 & 0,001 & 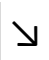 \\
\hline & & & & Micro-PS x FLU & 0,98 & 0,33 & 0,12 & 0,015 & $\uparrow$ \\
\hline \multirow{13}{*}{ Digestion } & $p k$ & T14 & G & Control & 0,72 & 0,20 & 0,07 & & \\
\hline & & & & FLU & 0,75 & 0,27 & 0,09 & $>0.05$ & \\
\hline & & & & Micro-PS & 0,82 & 0,32 & 0,11 & 0,023 & $\lambda$ \\
\hline & & & & Micro-PS x FLU & 1,07 & 0,24 & 0,08 & $>0.05$ & \\
\hline & & & & & & & & & \\
\hline & $p k$ & T14 & DG & Control & 1,06 & 0,41 & 0,14 & & \\
\hline & & & & FLU & 1,22 & 0,43 & 0,14 & 0,012 & 入 \\
\hline & & & & Micro-PS & 0,89 & 0,36 & 0,14 & $>0.05$ & \\
\hline & & & & Micro-PS x FLU & 1,54 & 0,48 & 0,17 & $>0.05$ & \\
\hline & amylase & T14 & DG & Control & 0,31 & 0,23 & 0,08 & & \\
\hline & & & & FLU & 0,50 & 0,35 & 0,12 & 0,006 & オ \\
\hline & & & & Micro-PS & 0,23 & 0,22 & 0,08 & $>0.05$ & \\
\hline & & & & Micro-PS x FLU & 1,02 & 0,79 & 0,28 & $>0.05$ & \\
\hline \multirow[t]{4}{*}{ Immunity } & lys & T7 & $\mathrm{G}$ & Control & 0,99 & 0,96 & 0,32 & & \\
\hline & & & & FLU & 1,07 & 0,64 & 0,21 & $>0.05$ & \\
\hline & & & & Micro-PS & 2,18 & 1,27 & 0,42 & 0,044 & $\pi$ \\
\hline & & & & Micro-PS x FLU & 1,18 & 0,74 & 0,25 & $>0.05$ & \\
\hline
\end{tabular}

